\title{
Legend and Legacy: Fifty Years of Defense Production at the Hanford Site
}

\author{
M. S. Gerber \\ Date Published \\ September 1992
}

Prepared for the U.S. Department of Energy Office of Environmental Restoration and Waste Management

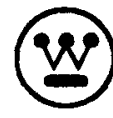

Westinghouse

P.O. Box 1970

Hanford Company Richland, Washington 99352

Hanford Operations and Engineering Contractor for the

U.S. Department of Energy under Contract DE-AC06-87RL.10930 


\section{DISCLAIMER}

This report was prepared as an account of work sponsored by an agency of the United States Government. Neither the United States Government nor any agency Thereof, nor any of their employees, makes any warranty, express or implied, or assumes any legal liability or responsibility for the accuracy, completeness, or usefulness of any information, apparatus, product, or process disclosed, or represents that its use would not infringe privately owned rights. Reference herein to any specific commercial product, process, or service by trade name, trademark, manufacturer, or otherwise does not necessarily constitute or imply its endorsement, recommendation, or favoring by the United States Government or any agency thereof. The views and opinions of authors expressed herein do not necessarily state or reflect those of the United States Government or any agency thereof. 


\section{DISCLAIMER}

Portions of this document may be illegible in electronic image products. Images are produced from the best available original document. 


\section{Contents}

Why Hanford's History Is Important $\ldots \ldots \ldots$. . . . . . . . . .

Pre-Site History of the Columbia Basin . . . . . . . . . . . . . . . 1

Site Selection Criteria and Hanford's Wartime Construction . . . . . . . . . . . . 5

World War II Operations and Early Development of Monitoring Programs . . . . . . 11

Postwar Production Lull (September 1945 - August 1947) . . . . . . . . . . . . . . 17

Hanford's First Postwar Expansion $(1947-1949) \quad \ldots . \ldots . \ldots$. . . . . . . . 21

First and Second Korean War Expansions $\quad(1950-55) \ldots \ldots . \ldots 25$

Peak Years of Production at the Hanford Site $(1956-63) \ldots \ldots . \ldots 31$

Hanford Site Wastes in the Columbia River . . . . . . . . . . . . . . . 35

300 Area Development . . . . . . . . . . . . . . . . . . . . 39

History of 200 Area Cribs and Tanks . . . . . . . . . . . . . . . . 45

Historic Structures at the Hanford Site . . . . . . . . . . . . . . . 51 


\section{Location and Regional Map of the Hanford Site}

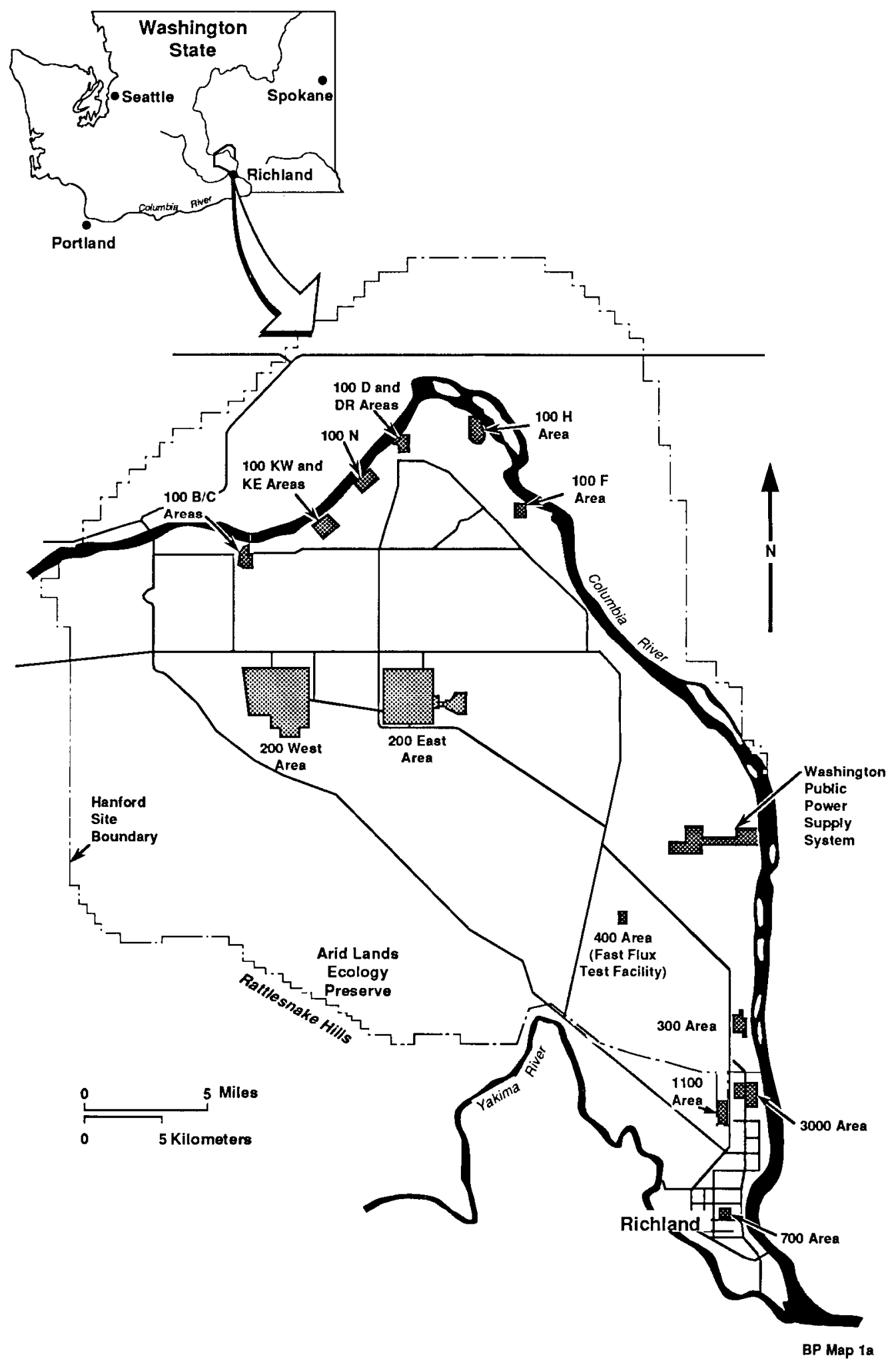




\section{Why Hanford's History Is Important}

Today, the Hanford Site is engaged in the largest waste cleanup effort ever undertaken in human history. That in itself makes the endeavor historic and unique. The Hanford Site has been designated the "flagship" of Department of Energy (DOE) waste remediation endeavors. And, just as the wartime Hanford Project remains unmatched in history, no counterpart exists for the current waste cleanup enterprise.

The extensive historical record, however, does provide a partial road map. The science of environmental monitoring pioneered at the Hanford Site, and records of this type are the most complete of any in the world, from private companies or public agencies, for the early years of Site operations. The Hanford Site was unique for establishing a detailed, scientific, and multi-faceted environmental monitoring program.

Historical data on the amounts and components of wastes discharged, from which locations and at which times, can guide and simplify the waste remediation program. It can help pinpoint where the most effective test wells should be dug and sometimes even reduce the need for expensive well drilling and well sampling. It also will provide information on wastes and residues that now are gone but that affected process, site location and construction decisions in the past. For example, the original, planned location of the Reduction Oxidation (REDOX) Plant was changed in March 1948 in response to particulate deposition studies.

Likewise, oral history interviews yield understanding of the alternatives that were considered when past decisions were made, the information available at the time, and ultimately why things happened as they did. A number of caring, intelligent, involved older people dialogue with Site researchers on every facet of past operations.

The leading reason for learning and understanding Hanford Site history is that the Site has taken the lead in open, public disclosure about its past. More historical data are publicly available about the Hanford Site than are available about any other defense nuclear site in the world. However, this openness has also focused the attention of the national media on this Site. Additionally, Hanford is being studied in three large federal projects: the U.S. Centers for Disease Control's Hanford Thyroid Disease Study and the Hanford Environmental Dose Reconstruction Project, as well as the National Park Service's Hanford Reach Wild and Scenic Rivers Study Bill.

The Hanford production mission generated two-thirds of all the nuclear waste, by volume, in the DOE complex. Nuclear waste is part of the Site's history and legacy. We have been challenged to clean up that waste in the next three decades. Remaining mindful of the history that has shaped today's Hanford Site will help us define tomorrow's Site. Some things will change; others will not. While secrecy was crucial to the early Hanford Site missions, today, openness is equally crucial. Dialogues with the public and with regulatory agencies over the best cleanup methods will produce better techniques. The goal of building a defense arsenal has changed to one of cooperating to pioneer waste cleanup, recycling, and re-use 
by sharing technology with other regional and national and even international sites.

The differences between secrecy and openness, and production and process are among the reasons that the "culture change" we hear about so much is difficult. We need to be gentle with each other, especially in dialogues between generations, as we work through this transition. However, the need for and ability to achieve technical excellence is a constant that was proven in Hanford's early years. That technical excellence is carried out today and must continue tomorrow. The commitment and pride of individual Hanford employees is also a constant.

During the year this document was written and compiled, the world witnessed some of the most historic events of our century. National leaders of the U.S.S.R. renounced the Communist Party. The central, monolithic control that had existed in that country since the Communist revolution of 1917 was abandoned in favor of a loose confederation of republics. Today, the new Soviet Union struggles to establish businesses and distribution systems that work as it forges wholly new political parties. Both the United States and the U.S.S.R. announced the largest cuts in nuclear weapons ever undertaken in the era of atomic/nuclear history.

In a very real sense, the Hanford Site helped cause and allow these magnificent events to take place. Hanford, as the largest workhorse weapons production site in U.S. history, met a fearful challenge during the years since its founding in 1943. It made the weapons that ended World War II and that helped win the Cold War. Unlike other wars that were fought on battlefields, the Cold War was fought and won at Hanford, Washington, and at the other U.S. defense production sites.
Today, we, along with other Americans, reap the rewards. The Soviet Union's economy could not withstand the costs of the long years of weapons production, and it has to be totally restructured. That nation is discovering the benefits of democracy and peace. It has paid a very high price. While we do not gloat, and while we do want to help them rebuild, let's take time to be grateful for the monumental production history of the Hanford Site. Without it, the course of history today might be far different.

An understanding of the Site's various names will aid the reader. The original name given by the War Department in early 1943 was the Gable Project. However, it soon became the Hanford Project, and then the Army Corps of Engineers and prime contractor E. I. duPont de Nemours \& Co. officially named it Hanford Engineer Works (HEW). HEW was renamed the Hanford Works (HW) when the Atomic Energy Commission (AEC) assumed control of the Site on January 1, 1947. Prime contractor General Electric Co. (GE) termed the Site the Hanford Atomic Products Operation (HAPO) as an internal corporate division in 1953, but the overall name Hanford Works stayed until the coming of the Energy Research and Development Administration (ERDA) in 1975. For two years beginning at that time, the Site was known as the Hanford Reservation. Since 1977, under the DOE, it has been officially named the Hanford Site.

This document compiles eleven articles written by Michele S. Gerber, Ph.D., originally published in the Hanford Reach. 
WHC-MR-0293

Revision 2

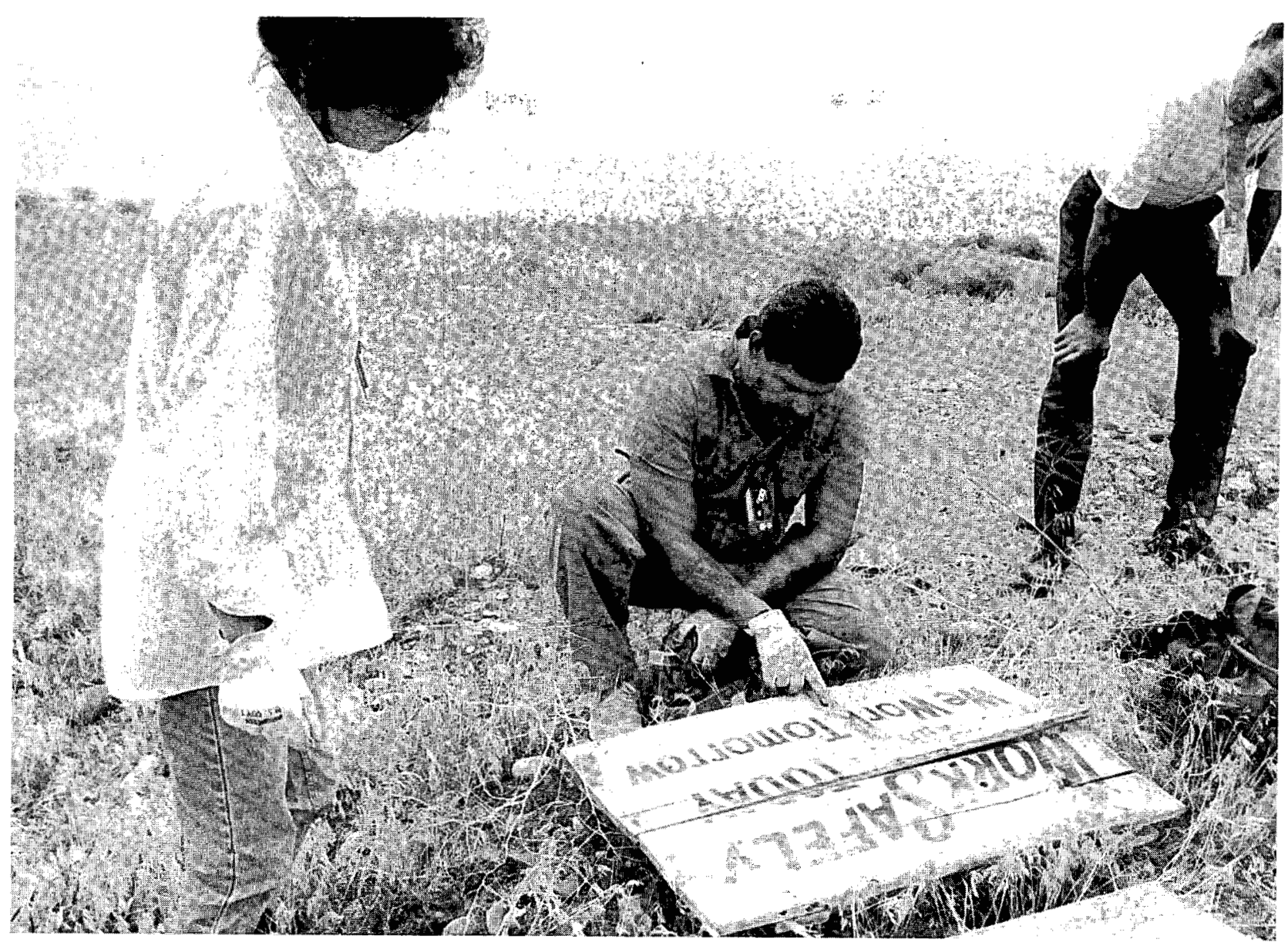

Hanford workers retrieve their history, discovering a cache of World War II signs, August 1991. Made of wood, these signs contain safety admonitions, performance records, color-coded meal and cafeteria information, traffic regulations and a series of street names designated for wartime battles and generals. State, local and national museums have expressed interest in exhibiting these unique signs. 


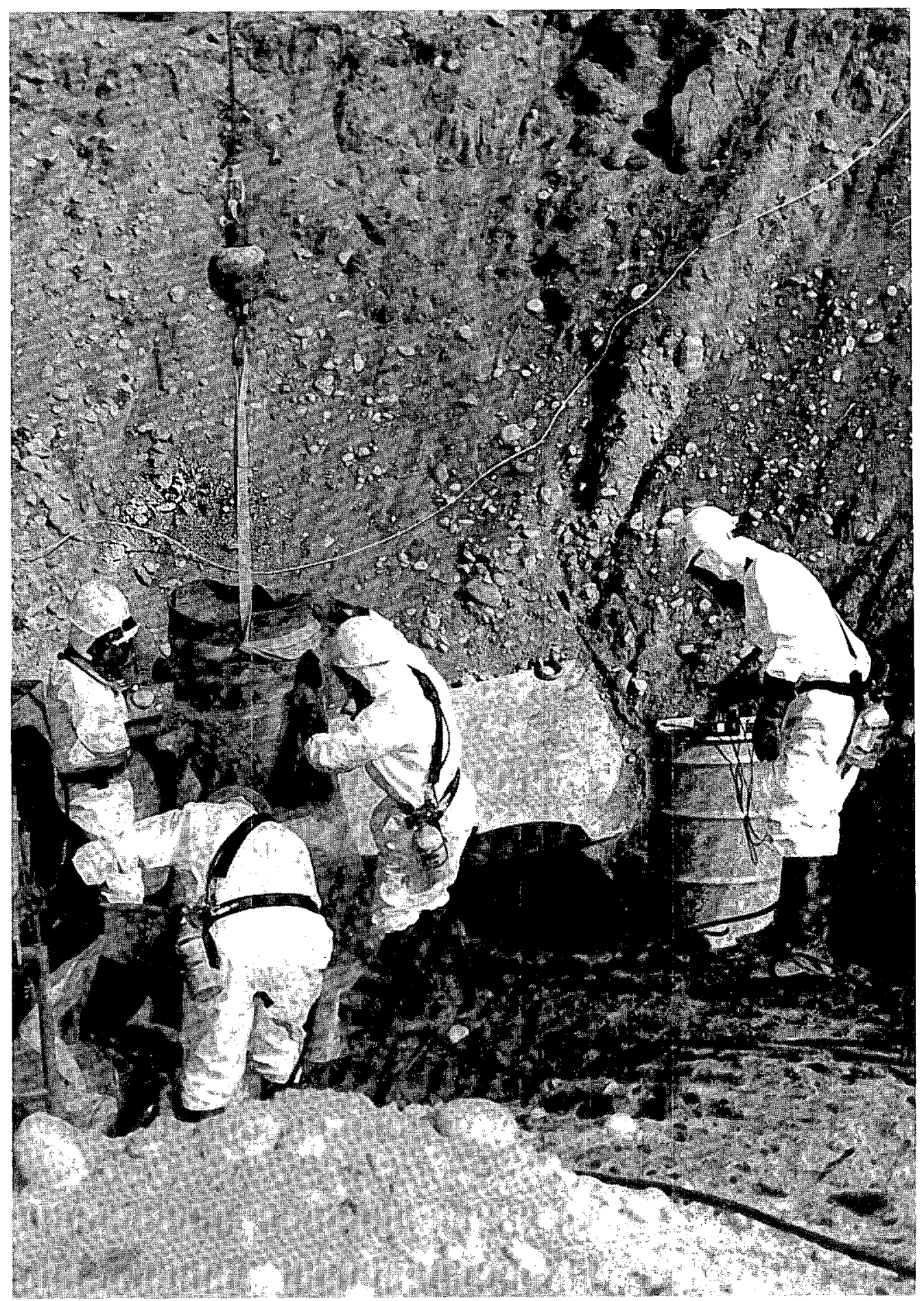

The waste cleanup in action at the Hanford Site: workers wearing protective clothing remove barrels containing hexone (methyl isobutyl ketone) from a burial site north of the 300 Area, March 1991. The hexone had been used in developmental experiments for the reduction oxidation process in 1949. 


\section{Pre-Site History of the Columbia Basin}

Colonel Franklin T. Matthias, Army commander at the Hanford Site during World War II, and one of the original three people to scout and recommend the Site for the location of the nation's first full-size plutonium production plants, called this region the Columbia Valley. Previously, other newcomers and visitors to the area had named it in various ways that reflected its features. The Great Forks and the Three Rivers called to mind the junction of the dazzling waterways, and the Great Columbia Desert indicated the dryness of the level plain.

This arid and ashy basin, scooped out by glaciers during the Pleistocene Age, is a very beautiful place. But it is not an easy land to live on, and it is unforgiving of the mistakes of those who do not make allowances for its chief characteristics -- the very powdery, volcanic soils, the clouds of dust that are raised from this sandy amalgam when the winds blow in, and the "crazy quilt" of a water table formed by seams and rifts in the underground basalt. The Columbia Basin was not attractive to the early nineteenth century non-Indians who explored it for routes, furs, business prospects and homes. It contained almost no wood for fuel, fencing, and house-building, and the climate was too dry to bode well for agriculture. For these reasons, the broad basin was settled by non-Indians later than was almost any other region of the contiguous United States except for the Texas Panhandle.

In June 1855, Washington's territorial governor Isaac Stevens, wanting to attract settlers to eastern Washington, held council with the Yakima, Cayuse, Walla Walla, Umatilla, Nez Perce, and various smaller bands of Native Americans. A reservation system was devised, but it did not fit the traditional food-gathering habits nor the family groupings of the Native Americans. After treaties were signed at the Walla Walla council grounds, the new system was largely ignored. In September 1858, a military expedition led by Colonel George Wright crushed the main forces of Native American resistance at the Battle of Spokane Plains. This step brought about compliance with the reservation system devised in 1855 .

$$
\begin{gathered}
\text { This beautiful basin ... "is not } \\
\text { an easy land to live on ..." }
\end{gathered}
$$

\section{The Gold Rush}

In 1858 and 1860 , gold was discovered to the north and east of the Columbia Basin, in British Columbia and in present-day Idaho. Many prospectors came and explored the entire length of the mid-Columbia River. Nothing was found in the Columbia Basin except a little float gold near Wenatchee. The prospecting surge did not result in the founding or growth of any major regional towns except Walla Walla and White Bluffs. Walla Walla, established in 1856 as a military post, boomed to become the foremost center for mining supplies and the transshipment of gold in the vast, unsettled expanse between the Cascade and Rocky Mountains. The White Bluffs landing, long a central crossing and debarkation point for local Indians, became the favorite place to ford cattle and supplies and to trade and purchase supplies at a small general store. 


\section{Ranching}

The most significant impact of the gold mining surge in the Columbia Basin, however, was the establishment of the first large, regional ranches. Ben Snipes, later known as the "Northwest cattle king," began the settlement. Beginning in the late $1850 \mathrm{~s}$, he blazed a cattle trail north from The Dalles, Oregon, across the mid-Yakima Valley and the present-day Hanford Site, and north to provision the British Columbian mines with beef on the hoof. Later, he blazed a trail eastward from the White Bluffs crossing to the Idaho mines. He established the first "permanent," non-Indian ranch in the Yakima Valley in 1859. A few other ranches, near the mouth of the Yakima, soon followed.

\section{The Railroad}

Ranching dominated the Columbia Basin until the Northern Pacific Railroad built south from Spokane through the region beginning in 1879. In 1882, searching for a flat place to bridge the Columbia River near its junction with the Snake, railway engineers platted and founded the towns of Pasco and Kennewick. Immediately, hoping to attract customers, the carrier began advertising the "lordly plain of the Columbia" in lavish fliers distributed throughout the Midwest. In the ten years ending in 1889, the Northern Pacific brought enough settlers to the northern tier that six new states were admitted to the Union in 1889 !

As soon as the Columbia Basin started to fill with settlers, the most urgent need of the newcomers became that for water for their crops. Small irrigation companies and farmers' cooperatives began in the region in 1888. However, they were undercapitalized and most went bankrupt in the national financial Panic of 1893. The area languished in a dusty haze until the Newlands Reclamation Act of 1902 made possible direct federal participation in the long-term financing of irrigation projects. Within two years, the Northern Pacific had formed a development subsidiary and rebuilt and extended most of the irrigation canals in the Basin. Additionally, new reclamation companies were formed.

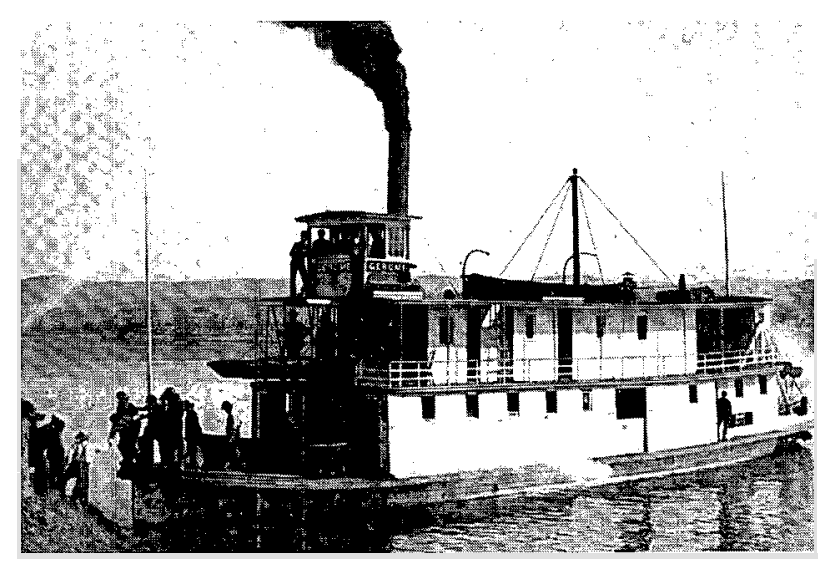

The steamboat Gerome, 82 feet long with a 16-foot beam, began daily freight and passenger service between Kennewick and the bottom of Priest Rapids in the busy development spring of 1905. Later that year, the vessel was modified to allow it to pass under the Northern Pacific rail bridge between Pasco and Kennewick and expand daily service downstream as far as Wallula.

The consequent boom in settlement and real estate constituted the largest population expansion in the history of the Columbia Basin, except for the coming of the Hanford Project in 1943. Between 1905 and 1910, the towns of White Bluffs, Hanford and Richland were officially founded. From that time until 1943, the region stabilized into a network of farms and small supply and grain shipment towns. There were small spurts of growth, 
brought about by the agricultural shortages and price rises of World War I and II, and by the coming of the Pasco Naval Air Station in 1942. There also were times of decline, caused by the pervasive drought of the 1920 s and by the Great Depression of the 1930s. The Depression hit very hard in the Columbia Basin, driving agricultural prices so low that a Washington State College study done in 1932 found that the average, annual disposal net income of a farm family in Benton County was $\$ 27.00$ ! Half of the farms in Franklin County were either foreclosed or abandoned in the first half of the 1930s. It took federal projects, especially the construction of the Grand Coulee Dam beginning in 1933, to boost the economies of the little Basin towns during this difficult time.

When the Army Corps of Engineers came to look at the Columbia Basin in late
December 1942, it found a region neither highly developed nor populated. Prosperity, where it existed, was moderate. A total of about 19,000 people lived in Benton and Franklin counties, nearly a fourth of them $(3,900)$ in the railroad town of Pasco. Kennewick held 1,800 people, and White Bluffs, Hanford and Richland combined had 1,500. The rest lived on regional farms.

Social life revolved around school, church and agricultural fairs, and almost all who have written about the Basin at this time have commented on the community closeness in the area. Perhaps the struggles to wrest a living from the windy, dry, open environment bonded the people to each other and to the stark and lovely Basin. 
WHC-MR-0293

Revision 2



Pumping plant for the Hanford Irrigation and Power Company, constructed in 1907-08 by Judge Cornelius Hanford of Tacoma, along with a consortium of Seattle-area investors. At the same time, Judge Hanford also platted the town that bore his name, about six miles south of White Bluffs. 


\section{Site Selection Criteria and Hanford's Wartime Construction}

The Hanford Site was selected for the location of the first, full-scale plutonium production plants in the world as the result of a series of important 1942-43 decisions. In 1940 and 1941, atomic research in the U.S. had been carried out by the federal Office of Scientific Research and Development. At first, the Office of Scientific Research and Development concentrated on the highly fissionable, but rare, isotope U-235 (uranium). However, in March 1941, a research group headed by physicist Glenn T. Seaborg at the University of California produced the first, submicroscopic amounts of Pu-239 (plutonium). Soon after the Japanese attack on Pearl Harbor plunged the U.S. into war in December 1941, the Office of Scientific Research and Development recommended that the Army Corps of Engineers be brought into the secret atomic project to blend practical application with laboratory research. President Franklin D. Roosevelt agreed, and charged the Corps with constructing industrial plants that could produce U-235 and Pu-239. To accomplish this task, a new division, the Manhattan Engineer District (MED) was formed within the Corps in June 1942. In September, the veteran procurement, site selection and supplies officer Leslie R. Groves was named to head the MED.

\section{Progress in the Face of Uncertainty}

Groves has affirmed that as soon as he assumed command of the MED, he made it his highest priority to visit the Metallurgical
Laboratory (Met Lab) at the University of Chicago, where some of America's most prestigious scientists were conducting the theoretical research that would drive the atomic projects. The practical, tough-minded Groves has stated that he was frankly "horrified" at the information he received: "It was as if the whole endeavor were founded on possibilities rather than probabilities." Major uncertainties faced the plutonium project. There were various potential methods for cooling the pile (reactor) in which the uranium would be irradiated. The means of subsequent chemical separations was unfixed. The equipment needed was not even designed or manufactured anywhere in the world as yet. And there was the question of maintaining health and safety in the presence of large quantities of new, dangerous, and poorly understood radioactive substances. Additionally, Met Lab scientists could not even guess to "within a factor of ten" the amount of fissionable material needed to make each atomic bomb. Nevertheless, it was Groves' philosophy that "nothing would be more fatal to success than to try to arrive at a perfect plan before taking any important step." He tackled the practical questions: what materials would be needed? what contractor had any experience that could help? where would the plants be located?

In the meanwhile, Met Lab and other MED scientists had been learning more and more about the processes that would be needed to produce plutonium. At meetings in June and October 1942, J. Robert Oppenheimer and other key bomb developers told Army and MED officials of their tests with various 
carrier solutions in the separations phase. According to Vincent Jones, historian with the U.S. Center for Military History, these experiments had rendered the scientists "duly impressed by the evidence of intense radioactivity... a fact which subsequently contributed to the decision in December to shift the plutonium production plant from Tennessee to another location." In November, the DuPont Corporation signed as prime contractor to construct and operate the plants. It added its weight to the contention that plutonium production should take place far from the populated East and Midwest. The ultimate siting decision fell to Groves.

\section{Site Criteria}

On December 14, 1942, meeting with DuPont officials and two of his top assistants, Colonels Kenneth Nichols and Franklin Matthias, he developed site criteria: The plutonium production facilities should be built on a large and remote tract of land, with a "hazardous manufacturing area" of at least 12 by 16 miles, space for laboratory facilities at least eight miles from the nearest pile or separations plant, no towns of 1,000 or more people closer than 20 miles from the hazardous rectangle, and no main highway, railway or employee village closer than 10 miles from it. Climate, it was decided, "theoretically should have no effect....although its bearing on the engineering problems should not be minimized." An abundant, clean water supply was needed, as was a large electric power supply and ground that could bear heavy loads.

Three days later, Matthias and two DuPont engineers, Gilbert Church and A.E.S. Hall, left to scout the western United States for such a site. When they had seen and explored the dusty tract lying between the towns of
White Bluffs, Hanford, and Richland, Washington, they reported to General Groves that the place was "far more favorable in virtually all respects than any other." Groves, after a January visit, concurred, and land acquisition proceedings began. In August 1945, the first public report on the Manhattan Project issued by the War Department would affirm that the Hanford Site was selected partly for its "isolation."

\section{Unprecedented Engineering and Construction Feat}

\author{
Once the land had been procured,
} construction proceeded at a nearly unbelievable pace. In just the 30 months between groundbreaking in March 1943, and the end of the war in August 1945, the MED built 554 buildings not dedicated to living requirements. Among the most prominent of these were B, D and F Reactors; T, B and U processing canyons; 64 underground, high-level waste storage tanks; and many facilities dedicated to fuel fabrication in the 300 Area. The Hanford Project also constructed 386 miles of automobile roadway, 158 miles of railroad, 50 miles of electrical transmission lines and four step-down substations, and hundreds of miles of fencing. Additionally, it built a new "government city" of Richland, capable of housing 17,500 people. The entire endeavor used 780,000 cubic yards of concrete and 40,000 tons of structural steel, and set many more milestones. It accomplished all this for a cost of $\$ 230$ million!

At wartime Hanford, secrecy reigned. Designs were compartmentalized, with only a few top engineers knowing the overall structure that a building would assume. Visiting MED scientists were given code names to veil their purpose and intent. In 
addition, uranium was called "base metal" and plutonium was called "product." Industrial recruiting efforts were veiled, with potential employees being told only that they would be "working out West," and "doing important war work." State and local officials were not informed about the purposes of the huge structures being erected in the desert, and even Vice President Harry S. Truman was not informed until after Roosevelt had died!
Naturally, with all that secrecy, Hanford Engineer Works was a huge rumor mill. The most prevalent rumors vowed that the complex manufactured high-powered airplane fuel, or chemical or germ weapons. Some of the funniest rumors dubbed it a summer home for President and Mrs. Roosevelt, or a factory to make fifth term reelection buttons for the President!

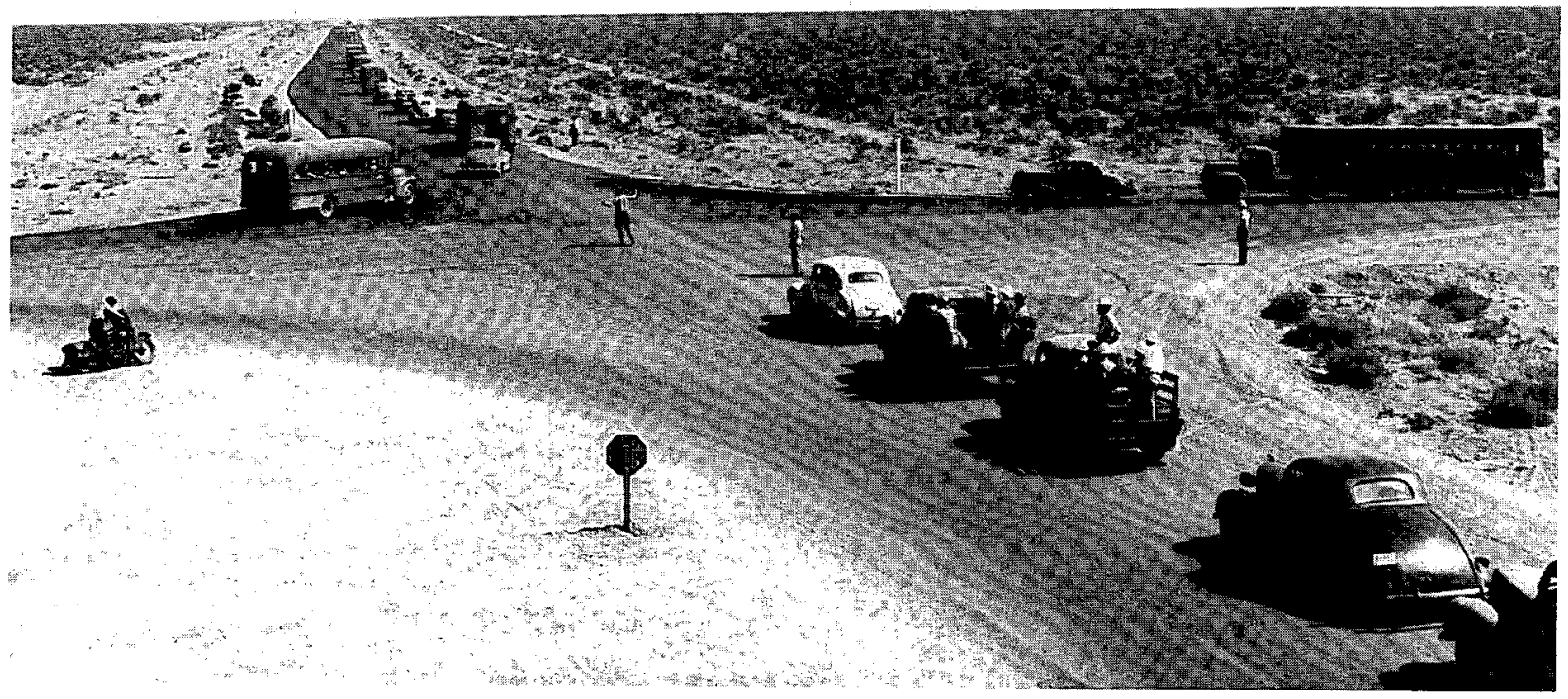

Traffic jams of Army and construction vehicles, bringing a deluge of materials and manpower, sprang up in 1943 on the eastern Washington desert, where previously sagebrush, Russian thistle, black-eyed Susans and jackrabbits had ruled. 
WHC-MR-0293

Revision 2

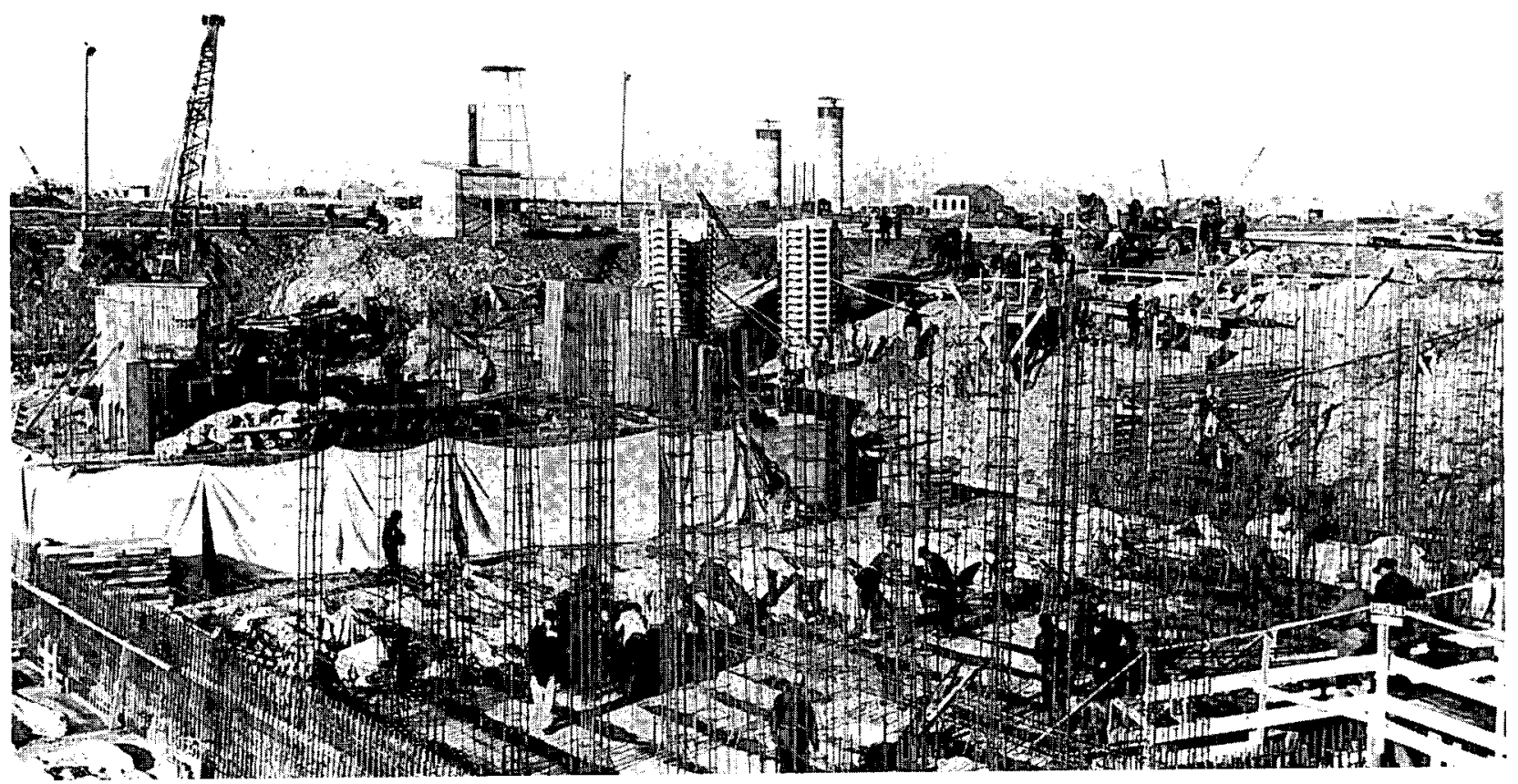

Reactor building under construction at wartime Hanford Engineer Works (HEW).

Originally, the work week consisted of six 8-hour days but in September 1943, was

extended to six 9-hour days. Additionally, shift work was added for the 100-B and 100-D

Areas, and huge floodlights were installed to permit around-the-clock construction.

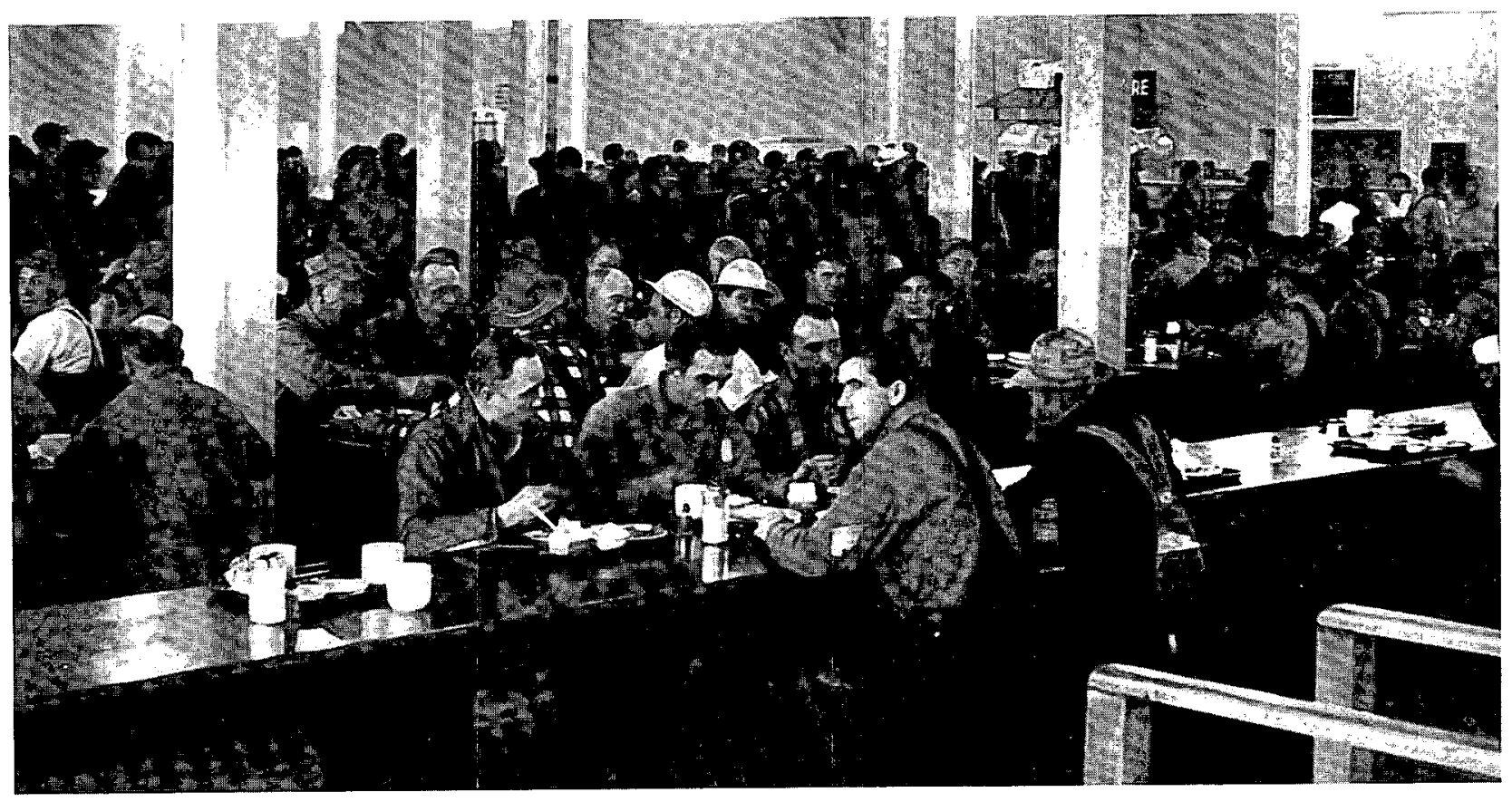

HEW workers converse over dinner in a cafeteria at the Hanford Construction Camp located at the old townsite built by Judge Cornelius Hanford. The camp housed 50,000 people at its peak in late 1944. In the dining halls, a coffee pot raised over the head was the signal for a refill. 
WHC-MR-0293

Revision 2



A neighborhood takes shape in government Richland, 1943. These two-family " $A$ " houses were among approximately 4,400 housing units built, in addition to dormitories, transforming a prewar hamlet of 400 people into a town capable of housing 17,500 people by 1945. 
WHC-MR-0293

Revision 2

This page intentionally left blank. 


\section{World War II Operations and Early Development of Monitoring Programs}

Aside from speed and secrecy, wartime operations at Hanford Engineer Works were most defined by the unique factor of radioactivity. The need to prevent radiation from seeping out through cracks and crevices brought new and distinct design and construction practices to the giant complex in the eastern Washington desert. Additionally, the new sciences of health physics and environmental monitoring developed rapidly at the Site, pioneering advances in instrumentation procedures, radiological working conditions, and methods of analytical chemistry to process substances never before sampled.

\section{Remote operation and repair capabilities} were essential, and extremely precise engineering tolerances were necessary. In the graphite reactor cores, cross-section measurements were permitted to deviate by only .0005 inch, longitudinal measurements by .006 inch, and the diameter of the holes for the process tubes could vary by only .003 inch! Because radioactivity could escape through even the smallest leaks, nails had lead-covered heads, and lead sheeting in the Hanford production facilities was overlapped at the joints. Because radiation could escape, all of the areas where radiation would be present were equipped with ventilation systems that sucked air inward.

\section{Progress Despite Wartime Shortages}

The highly corrosive nature of the chemical/radionuclide mixtures used in the bismuth phosphate separations process, as well as the wastes going to high-level storage tanks, demanded that a high grade of Colombian (Austenitic) stainless steel be used whenever possible. In some cases, wartime shortages of this material resulted in the substitution of lower grades of steel, and even of earthenware, in the fans, ductwork, pipes and water jackets of separations facilities and tanks. Throughout the war, these and other procurement difficulties pressed the Hanford enterprise. Heavy-gauge railroad track, cement, copper, lumber, iron, electrical wire, graphite and aluminum were always in short supply. In order to keep the project secret from even the War Production Board, Hanford was not given the highest priority ratings (AAA) for procurement and transport. However, in a complicated wartime system, the Hanford project could acquire an overriding priority when necessary.

\section{Large-Scale Innovation}

The innovative nature of the Hanford plants has been noted by many of the principals. General Leslie R. Groves, chief of the Army Corps of Engineers' Manhattan Engineer District (MED) has pointed out that "it is essential to keep in mind the truly pioneering nature of the plutonium development... gigantic steps [were taken]... moving rapidly... from the idea stage to an operating plant." The scale had to be huge. A crucial consideration was the minuscule amount of plutonium that could be expected from even full-scale operations. The Hanford prototype, the plutonium processing semi-works at Clinton, Tennessee (now Oak Ridge), was 
designed to separate one-tenth gram of plutonium per ton of reactor output! Groves has stated that when MED scientists spoke of "quantity production" of plutonium from the Hanford complex, they "did not mean tons per hour, but rather a few thimblefuls per day."

\section{Foundations for Worker Health and Safety}

Although good plant design could provide the basics of protection from radioactivity, MED leaders knew that the Hanford Engineer Works would need a team of onsite experts in the new science of health physics. A school was established at the Clinton Engineer Works. There, English physicist Herbert M. Parker, X-ray diffraction scientist Carl C. Gamertsfelder, and physician William D. Norwood, along with about 15 others who would constitute Hanford's initial health protection and instrumentation teams, trained for five months in early 1944 . They arrived at the vast Hanford tract in July 1944 and established an umbrella organization known as the Health Instruments (H.I.) Section. (This section later expanded to become a division, and consumed four percent of Hanford's budget and personnel by 1950.) The H.I. Section was charged with defining and measuring radiological hazards, establishing procedures to make jobs in plutonium production safe for workers, and developing and calibrating instruments. Parker, Gamertsfelder, and Norwood consulted frequently with leading figures of the era in radiation protection, such as Drs. Karl Z. Morgan and Simon Cantril of the Clinton Laboratories, and Drs. Giaochinni Failla and Robert F. Stone of the University of Chicago's Metallurgical Laboratory.

\section{Protecting Against the Unseen Danger}

The job of the H.I. Section was especially difficult because strict MED security regulations precluded revealing to most employees even the existence of radioactivity. Additionally, onsite Army commander Colonel Franklin T. Matthias worried that if workers became concerned about radioactivity, "this might be disastrous to the project as it might cause a large number of people to leave." Yet, rules had to be instituted to guard against a danger that employees could not see, taste, feel or smell. While information disclosure was held to a minimum, regulations were strictly enforced. One worker in Hanford's 231 Building (Plutonium Isolation) has recalled that she felt like Shakespeare's Lady Macbeth, because "we all washed our hands so many times a day...Wash it, scrub it, paint it, check it and sometimes dispose of it. I never cleaned so much stuff that already looked clean...Rules were simply stated but rigidly enforced." Eating, drinking and smoking all were strictly prohibited from the workplace.

A number of new and unique environmental monitoring instruments were placed into use at Hanford, including integrons (air monitors placed at 29 locations on and off the project), gas and liquid sampling vessels, and Geiger-Mueller counters and other devices for personnel monitoring. Film badges and two small, thin ionization chambers ("pencils") were worn by every employee on every shift. The pencils were read once a day, and the film badges once a week. Finger rings, alpha monitors ("poppies"), and urine checks also were used to survey employees who worked directly in "danger zones." In June 1945, in response to unexpectedly high levels of Iodine-131 
evolution, routine thyroid checks were begun among workers in the 200 Areas. At that time, the H.I. Section, which DuPont had intended to "gradually diminish," expanded. Hanford's workers displayed the human tendency to normalize the unfamiliar and unnerving new instruments by giving them comical nicknames. Betty Snoop, Cutie Pie, Queenie, Big Sucker, Little Sucker, Hot Dog Grill, Walkie-Talkie, and Horizontal Pig were some of the names bestowed (and some of these names are still used today!).

The magnitude of the early environmental monitoring job at the Hanford Engineer Works can begin to be grasped when it is realized that in the first eight months of 1945 alone, over one million pencils and over 170,000 film badges were measured, 52,000 instrument checks and over 157,000 hand checks were performed, and over 31,000 surveys of operating conditions were conducted in the 200 Areas alone. At the same time, surveys of vegetation were expanded far afield of the Hanford Site, and routine monitoring of Columbia River water and aquatic life, and project groundwater, were established. It should be recalled that this commitment and level of worker and environmental protection took place in a wartime environment when money and manpower were always in short supply.

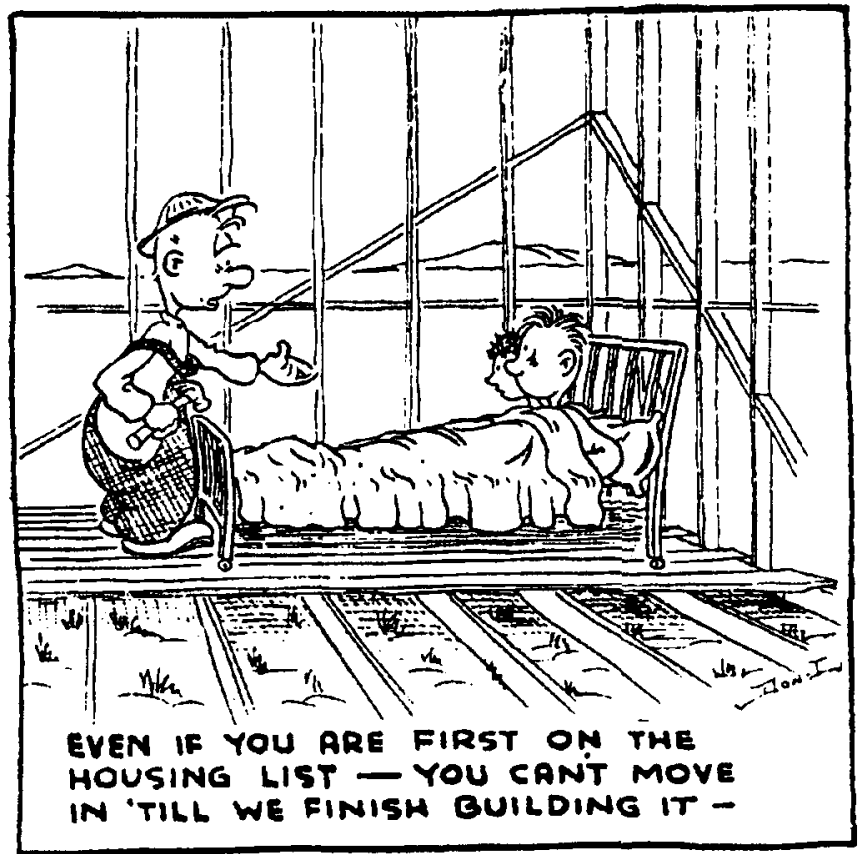

The Dupus Boomer cartoons, so named for DuPont, U.S., and "boomer" - a term applied to workers who moved from one booming government project to another, were begun in the Richland newspaper in 1945. Drawn as a hobby by engineer Richard Donnell, the cartoons poked fun at the shortages and other problems of rapid growth in booming Richland. 


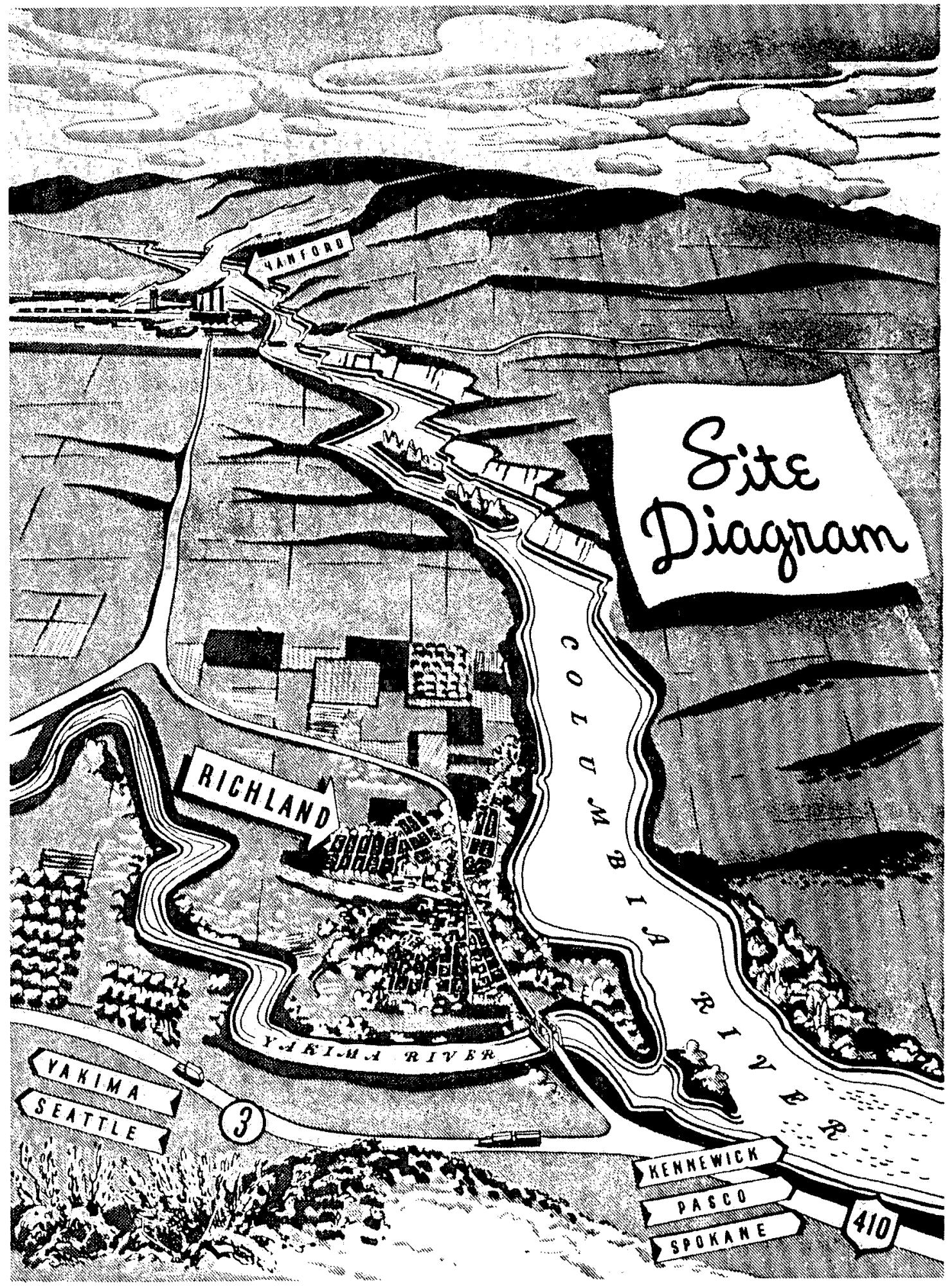

First official "map" of the Hanford Site to be released to the public. This wartime DuPont Corporation design sketch was offered to the radio and print journalists who swarmed to Richland hungry for news when President Truman announced the story of the Manhattan Project in August 1945. 
WHC-MR-0293

Revision 2

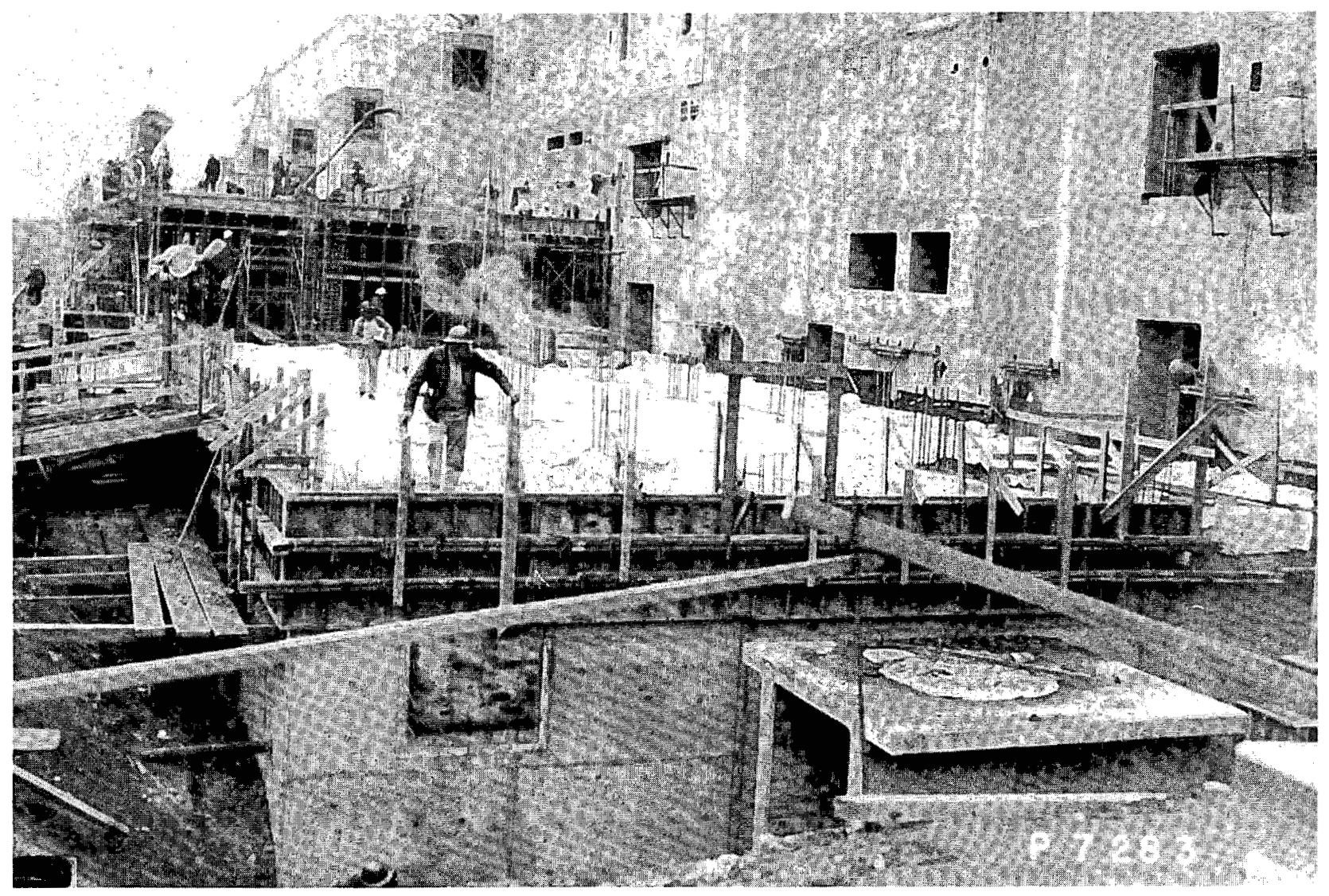

$T$ Plant, the first large.scale plutonium separations chemical facility in the world, under construction in 1944. Eight hundred feet long, and consisting of a series of cells surrounded by massive concrete shields, $T$ Plant and two similar plants built at wartime HEW were termed Queen Marys or "canyons" by workers. 


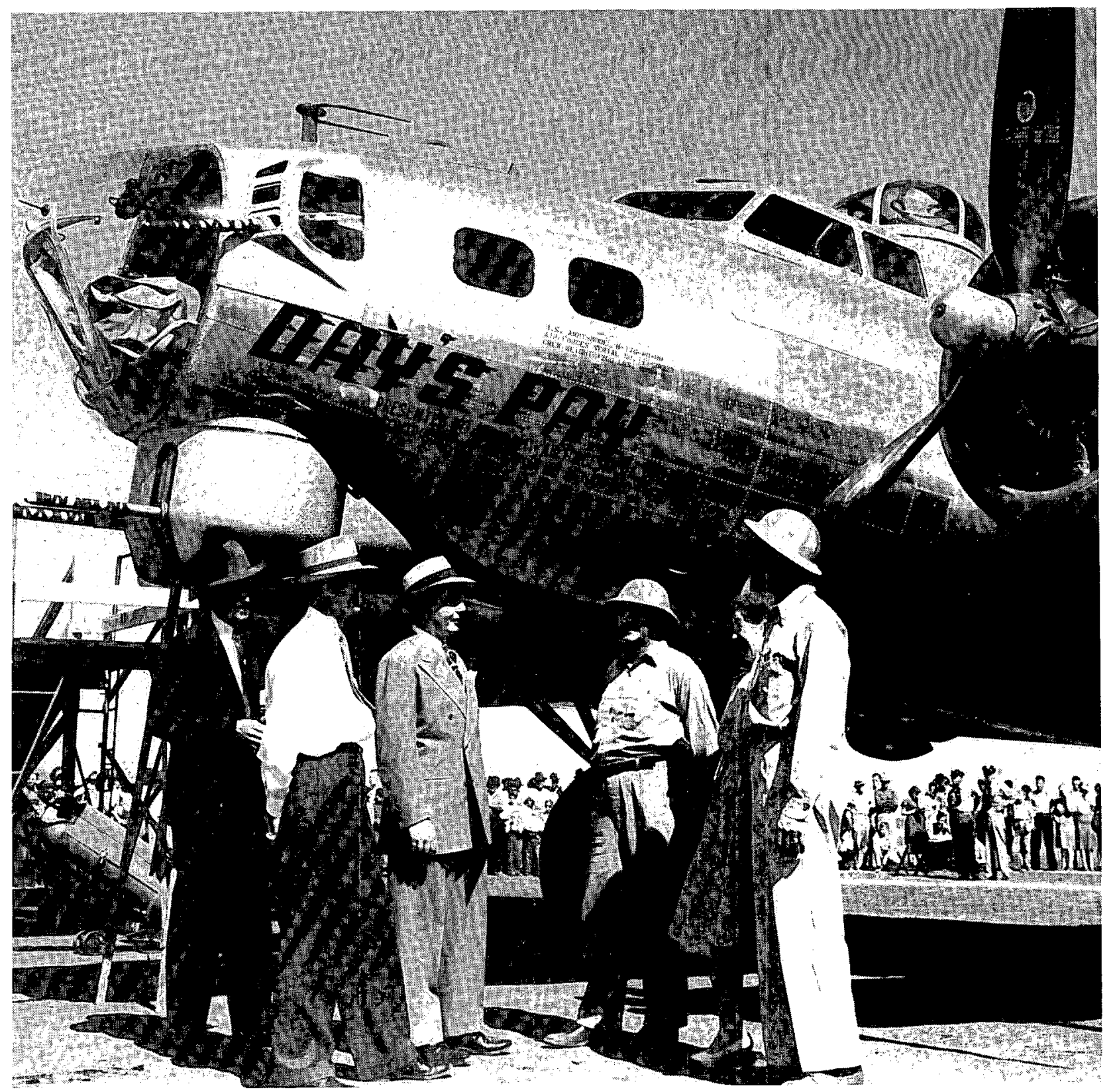

Dedication ceremonies in July 1944 for the "Day's Pay," a B-17 bomber bought for the Army Air Corps by HEW workers, each of whom contributed a day's pay. The plane later served with the Eighth Air Force in England. In March 1945, its crew was decorated with the Air Medal, five oak leaf clusters, and two major battle stars. 


\section{Postwar Production Lull (September 1945 - August 1947)}

The initial unveiling of the Manhattan Project in national press releases of August 6 and 7,1945, brought a rush of reporters to Richland. They found an enthusiastic and dedicated group of war workers. Hanford Engineer Works commander Colonel Franklin T. Matthias described a "consciousness in the minds of people directly working on the Hanford Project that they have contributed to the mechanism that will certainly end the war very soon." The Japanese surrender on August 14, just five days after the bomb containing Hanford's plutonium was dropped on Nagasaki, produced "rejoicing" in Richland. The "atomic city's" victory celebrations were covered in newspapers and on radio programs throughout the nation, and the little city basked in admiration and praise. Matthias expressed local feelings succinctly: "We of the Hanford Engineer Works are proud of our job. We are proud of our community." Overall Manhattan Engineer District (MED) chief General Leslie R. Groves came in October to laud Hanford employees and to present the Army-Navy "E" Award, the highest civilian production commendation, to all of them. The War Department authorized "A-Bomb" pins, bearing mushroom clouds, to be given to all MED workers. Matthias received the Distinguished Service Medal, and Major J. F. Sally, Army onsite production chief, was given the Legion of Merit Award.

\section{Peaceful Use for the Atom}

Despite the great mood of exhilaration and victory, early postwar Richland was as puzzled as the rest of the nation over what to do with the new power of atomic energy. Certainly, Richlanders were interested in pursuing peaceful uses for the awesome energy. Washington Senator Warren Magnuson highlighted Richland's role in the development of the peaceful atom in a 1946 speech: "Richland is a symbol...Richland's voice is strong... The atomic bomb workers...can lengthen the peace they hastened." That spring, the village sponsored its own "Win-The-Peace" contest, with speeches, symposia, and other public forums. A winning essay was written by Carolyn Hageman, the wife of a DuPont production engineer. She asked: "Are our hearts as big as our brains? ...Our problem is how to make nuclear physics contribute to human comfort, human knowledge and hence to human dignity."

\section{Where To Go from Here}

Aside from the challenge of the peaceful atom, early postwar Richland, along with the rest of the United States, wondered whether the atomic plants would close, or how they would be administered if they remained open. President Harry S. Truman, through financier Bernard Baruch, first offered a phased-in control of atomic energy and weapons to the United Nations. However, the Soviet Union, racing to develop its own bomb, vetoed the plan. The U.S. then sought to formulate legislation to place its atomic facilities under civilian control. Delays and Congressional wrangling characterized these efforts throughout 1946. General Groves has recalled: "With the ending of the war there was no national [atomic] policy. The only 
guidance that I could obtain was that I should continue to operate the project as I thought best." Throughout late 1945 and most of 1946, the MED adopted essentially a caretaker position. In fact, it instituted cost savings measures that reduced the output of fissionable materials at Hanford and at America's other large production facility, the Clinton Engineer Works in Tennessee (now Oak Ridge). At Hanford, this policy resulted in the decrease of power levels at $\mathrm{D}$ and F Reactors. In December 1946, B Reactor was closed completely, in order to preserve it as a future source of polonium-210, the essential initiator material in early atomic explosions. Throughout the MED, much of the scientific research staff became discouraged by the lack of challenges and left. At Hanford, the number of contractor personnel fell by half, from 10,000 to 5,000 , from September 1945 to December 1946.

During the same period, many government officials and members of the public began to worry about the confused state of U.S. atomic policy and slowed defense production. In 1946, William L. Borden, a young law student who later worked as an Atomic Energy Commission (AEC) official, published a small but influential book on defense strategy in the atomic age. In There Will Be No Time, Borden argued that atomic war would allow no time for defense preparations once hostilities had begun. $\mathrm{He}$ asserted that a national program of stockpiling weapons, a new and troublesome concept for many Americans, should begin immediately. His readable and quotable little book became immensely popular and prompted many citizens to write their Congressional representatives in favor of new arms production. At the same time, the MED's Advisory Committee on Research and Development, consisting of prominent scientists such as bomb developer

\section{J. Robert Oppenheimer, also became} concerned. It proposed large research and development budget increases for fiscal 1947. General Groves endorsed these increases and sited the nation's first three atomic national laboratories - Argonne (Illinois), Brookhaven (New York) and Oak Ridge - in late 1946.

\section{The Civilian Atomic Energy Commission}

The new civilian AEC, finally formulated in the McMahon Atomic Energy Act of 1946, took control of the U.S. atomic complex, including Hanford, on January 1, 1947. Meeting early in the year after a whirlwind tour of the production sites and laboratories, the AEC's General Advisory Committee assigned its highest priority to weapons research and production. By February, improvement and expansion of the plutonium production units at Hanford topped the list of AEC goals. Concurrence on the need for such actions came from many high-level sources. The Joint Chiefs of Staff of the armed service branches declared in March that the weapons supply was "not adequate," and a solemn President Truman, conferring with AEC chairman David Lilienthal on April 2, agreed. In March, Truman "declared" the Cold War in a speech calling for military and economic aid to Greece and Turkey, countries he said were struggling against stealthy Soviet intervention. Four months later, the U.S. passed the National Security Act, and Policy Planning Staff chief George F. Kennan penned his famous article advocating the "containment" of communism and other Soviet influence.

\section{Expansion Announced}

With national consensus mounting for more weapons production, the $\mathrm{AEC}$ made the 
decision to expand the Hanford Works. In a series of spring directives, the General Electric Company (prime site contractor since September 1946) was directed to build two new production reactors and to develop the new reduction oxidation separations process as quickly as possible. In August 1947, the massive, upcoming expansion was announced in Richland. Residents expressed relief and joy that their important work would go forward. Tri-City businesses, which had been slumping, revived. The largest peacetime construction project in American history up to that point was about to begin.

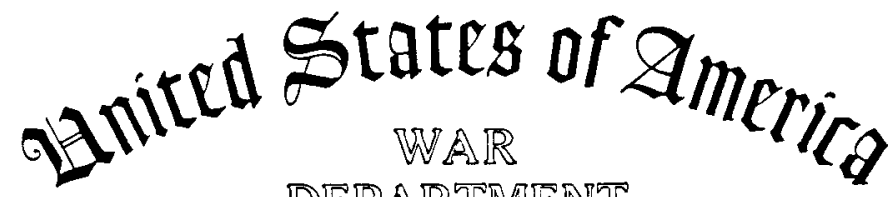 DEPARTMENT \\ $A R M Y S E R \mathbb{R} I E$ FORCES - CORPS OF ENGINEERS} itlanhattan Bistrict

$$
\begin{aligned}
& \text { This is to Cextify that } \\
& \text { winton s. szulinski } \\
& \text { E. 1. oupont de Nerours o co. inc. }
\end{aligned}
$$

has paxticifated in morfo essential to the froduction of the Attamic Promb, therely contributing to the successful conclusion of Hoxld Max II. This centificate is awasded in appreciation of effective service. 6 Shgual 1945

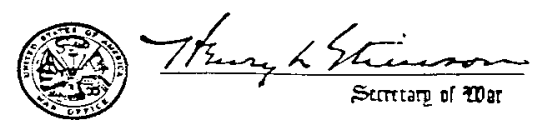

Hastington, $\mathscr{D} \mathscr{C}$.

Army-Navy "E" Award, the highest civilian production award of WWII, was presented to HEW workers in October 1945, by General Leslie R. Groves, chief of the Manhattan Engineer District. Signed earlier by Secretary of War Henry Stimson, this particular award went to Milton J. Szulinski, key figure in wartime chemical processing operations at Hanford. 
Desert Richland's attempts to grow green were the most frequent topic of Dupus Boomer cartoons. The pervasive construction excavations slit the fine, ashy soil in so many places that blowing dust and sand buried newly planted lawns, trees and shrubs. The Richland Dust Control Committee repeatedly distributed free seeds and seedlings to residents trying to anchor the powder.

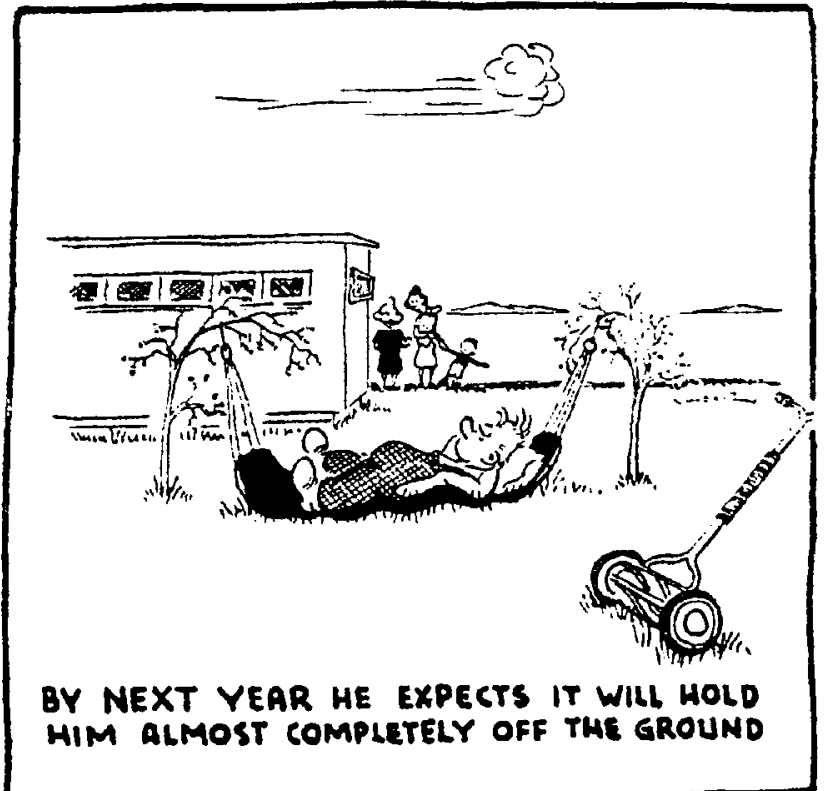

\section{$\overline{\text { EXTRA }}$ THE RICHLAND VILLAGER $\overline{\text { EXTRA }}$} EXTFA General Electric Desires to Retain Present Plant Working Force

Here Are the Official Announcements As Released by Companies and Government

The War Department anncunced a contract with the General Electric Company for Atomic Research and Development, includ ing the transfer of responsibility for operation of the $\$ 347$ million dollar government-onned plant at Hanford, Washington, from $E$ I. du Pont de Nernours \& Company.

The transfer will become effective approximately September 1,1946 , with the Government retaining general control over the piant: Under the new contract, General Electric will-

coiduct an extensive research program. It was at the urgent request of the Government Statement at a time of National Emergency that the du Pont Issued $B$ eration of the Eanford Works for militigry purposes

The the Eanford Works for mith inderaken with the inten ex-

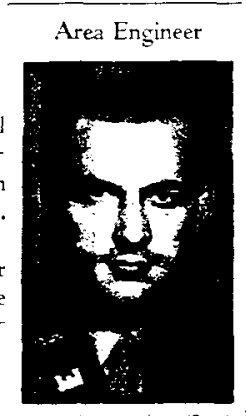

Any Changes Will Be In Upper Management Brackets Only States the Area Engineer

The War Department announced this moming that a contract had been arranged with the General Electric Company for the operation of the Hanford Encineer W'orks. The transfer will becom effertive approximately September 1, 1946, and will transfer the responsibilities for the plant and village here from the du Pont Com pany to General Electric, "with as fer changes in personnel as pos sible."

The changes which are made will be in the upper managemen brackets only, according to a release issued by Colonel F. J. Clarke, Du Pont President area Engineer of the Hanford plant and goiemmen: The change will boce affere the Du Pont President area The go over the plant.

Extra edition issued by Richland's newspaper in June 1946, proclaiming a change in the prime contractor later that year. To most Hanford workers, the change signified the fact that HEW would not be terminated like most other wartime ordnance plants, but would have a future mission in the development of atomic energy. 


\section{Hanford's First Postwar Expansion (1947 - 1949)}

The expansion of the Hanford plants and the city of Richland that occurred from 1947-49 was the largest peacetime construction project in American history up to that point. It cost more than the original building of the Hanford Engineer Works from 1943-45 (\$350 million compared to $\$ 230$ million). However, with the lifting of World War II price controls and a booming postwar economy starting in 1946, the cost differential was really not as great as it seems.

\section{New Production Capabilities}

During this expansion, $\mathrm{H}$ and $\mathrm{DR}$ reactors were constructed, with operations beginning in October of 1949 and 1950, respectively. $\mathrm{Z}$ Plant, or the Plutonium Finishing Plant, also was built. Before the operation of this facility, plutonium had been shipped from the Hanford Works to Los Alamos as plutonium nitrate, a wet paste. The Plutonium Finishing Plant made possible the conversion to hockey puck-shaped plutonium metal, known as "buttons," through the oxalate, oxide, and fluoride steps. Forty-two additional high-level waste storage tanks were also constructed during this expansion, and the Hanford Works became unionized. The Hanford Atomic Metal Trades Council was formed in 1948 and was certified officially by the National Labor Relations Board in February 1949.

During this same period, site chemists worked intensely in the old Analytical Chemistry Laboratory (3706 Building) on the development of the reduction oxidation (REDOX) process. The Atomic Energy Commission (AEC) insisted on rapid completion of this new method of chemical separation to save scarce uranium that was wasted in the first precipitation cycle of the old bismuth-phosphate processing. In 1949, Hanford Works planners also initiated completion of C Plant in 200 East Area as a "hot semi-works" (pilot plant) for the REDOX process. C Plant had been started during World War II as the fourth chemical separations canyon. However, as soon as the exhaust stack was up and the foundation was dug, Army engineers could see that such a facility would not be necessary. Wanting to save money and manpower, they simply built a pad over the foundation and left the stack in place. Five years later, they found a new need and finished the "hot semi-works."

\section{Richland Grows}

Other key developments during the 1947-49 expansion concerned the city of Richland. At that time, Richland was strictly a government city. It actually was a part of the Hanford Works, and was a city where you had to live if you worked in Hanford operations, and where you could not live if you were not a permanent Hanford operations employee. During the 1947-49 expansion, the AEC built new housing on the west side of Richland, and the city grew from about 17,500 people to about 23,000 .

During this same two-year period, the construction worker enclave of North Richland was founded to provide temporary housing to the people needed for the vast building projects. It was located five miles north of the then-current border of Richland and encompassed the area now occupied by 
the Supply System headquarters and the Pacific Northwest Laboratory regional office building. Barracks for single men were floated by barge up the Columbia River from the old Pasco Naval Air Station, and small trailers were procured for the men who brought their families.

\section{Boom Town}

By the summer of 1948 , just one year after its establishment, this trailer and barracks community housed about 12,000 construction workers and about 13,000 of their family members. The John Ball School was opened that autumn to provide grade 1-8 education for the children of North Richland, and this school's population soon peaked near 5,000 children. It was closed in 1955 after Hanford's three major postwar expansions were finished. Overall, the Tri-Cities regional population expanded to about 65,000 people during the 1947-49 expansion. Block I of the huge Columbia Basin Irrigation Project, a federal family farm development project, was opened for settlement in May 1948.

However, Block I was a tract of only about 5,400 acres directly north of Pasco.

Large-scale development of the farm plots farther north in Franklin County did not occur until the mid and late 1950s.

\section{Atomic Age Utopia}

Richland "village" as it was known in the 1947-49 expansion period, was a busy and energetic place. By 1948, over 2,000 babies had been born at Kadlec Hospital, and the village had the highest birth rate in the nation! The birth rate hovered at record highs throughout the mid and late 1940s, and maternal deaths, infant deaths, and deaths from other causes confounded national averages by being so far on the low side.
Residents quickly formed a large number of professional and social clubs, and Richland became the first city in the U.S. to adopt a "sister city" in Europe on an ongoing, charitable basis.

\section{Optimism Amid Growing Pains}

Visitors were enchanted by the optimism and vigor of Richland. In 1949, Time magazine termed it a "model residential city...an atomic age utopia." Nevertheless, there were problems in the booming village. Some difficulties were mundane ones that affected any area beset by rapid development, and some were uniquely related to the atomic activities at the Hanford Works. There were frequent power outages as electrical transmission lines underwent constant expansion, and there was an acute housing shortage. Billowing construction dust was ever present. However, according to AEC records, radioactive particulates, iodine-131 and nitrous oxide fumes sometimes burdened the dust, and local officials undertook a vigorous tree and grass planting effort to anchor down the powdery amalgam.

Additionally, what the community newspaper described as a "mosquito plague" beset Richland every spring and summer beginning in 1945. For several years, large amounts of DDT were sprayed throughout the town and along the Columbia River to control these pests.

\section{Cold War Grows Colder}

Meanwhile, as Richland and the Hanford plants grew, the Cold War worsened. The Soviet Union precipitated a communist coup in Czechoslovakia and initiated a blockade of the city of Berlin in 1948. The U.S. responded with the Marshall Plan to aid economically unstable areas of Europe, and 
with the Berlin airlift (an 11-month ordeal). Congress passed a resolution affirming the American policy of "collective self-defense" in 1948. That same year, President Truman was reelected on a platform that strongly advocated the "containment" of communism. Normally Republican Benton County supported the Democrat leader overwhelmingly. In 1949, the two "blocks" of nations, communist and non-communist, each formed mutual assistance pacts - the North Atlantic Treaty Organization in the case of the U.S. and its allies, and the Warsaw Pact in the case of the Soviet Union and its satellites. However, by late summer of that year, American officials were growing much more comfortable with the nation's state of defense readiness. Secretary of State Dean Acheson declared in July that the "position of the West...[has] grown greatly in strength, and that the position of the Soviet Union...has changed from the offensive to the defensive." Just two months later, Acheson and others would be confounded by an astonishing new development that would vastly alter the defense equation and would plunge the Hanford Works into another huge expansion.

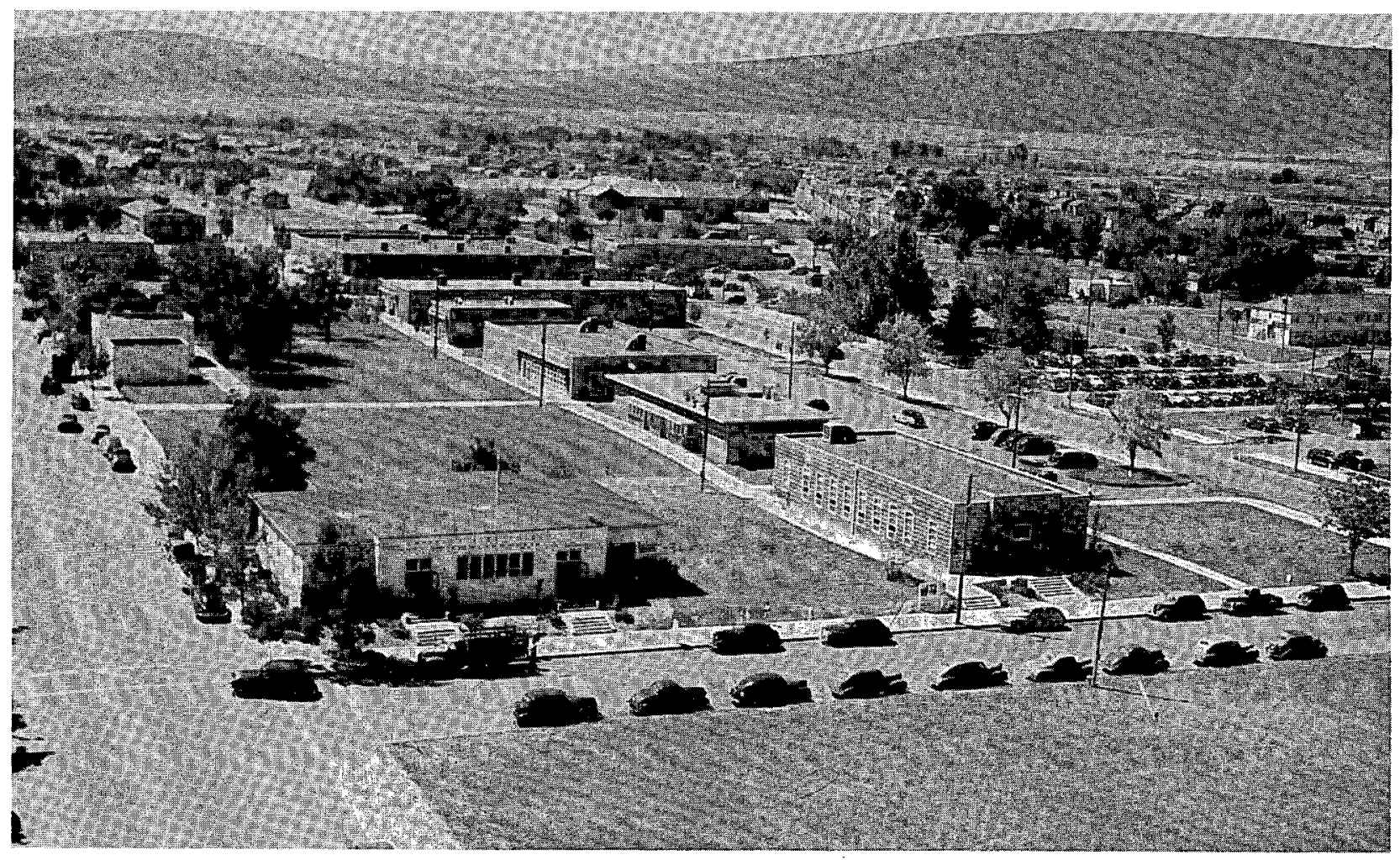

Downtown Richland, looking south toward Badger Mountain, about 1948. In the foreground is John Dam Plaza, then empty but now a treed park. The old government Post Office sits at the head of The Parkway, a pedestrian commercial district. 


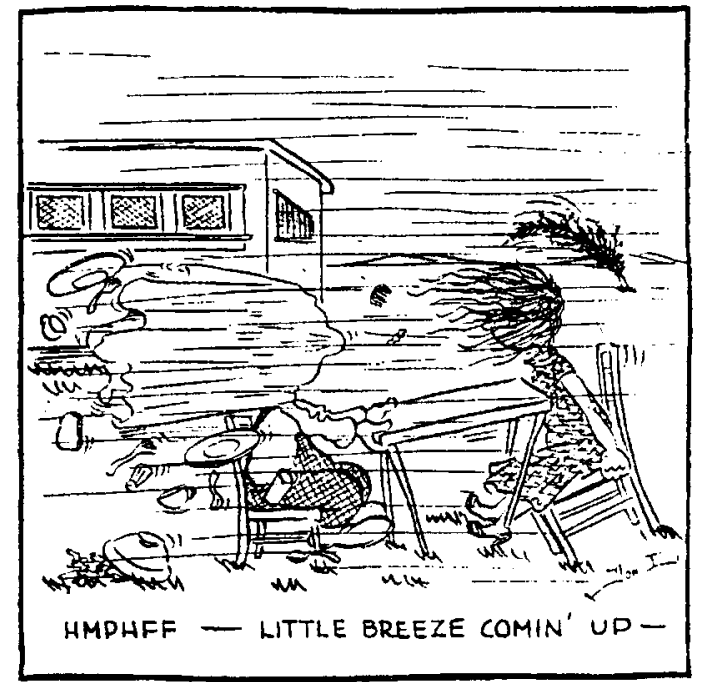

Dust storms rose up with new fury in the 1947-49 expansion period. A large shelterbelt of trees, planted on the western edge of Richland to break the prevailing winds, had to be torn up and moved farther west as the town grew rapidly. Excavations and construction traffic rivaled that of the WWII period.

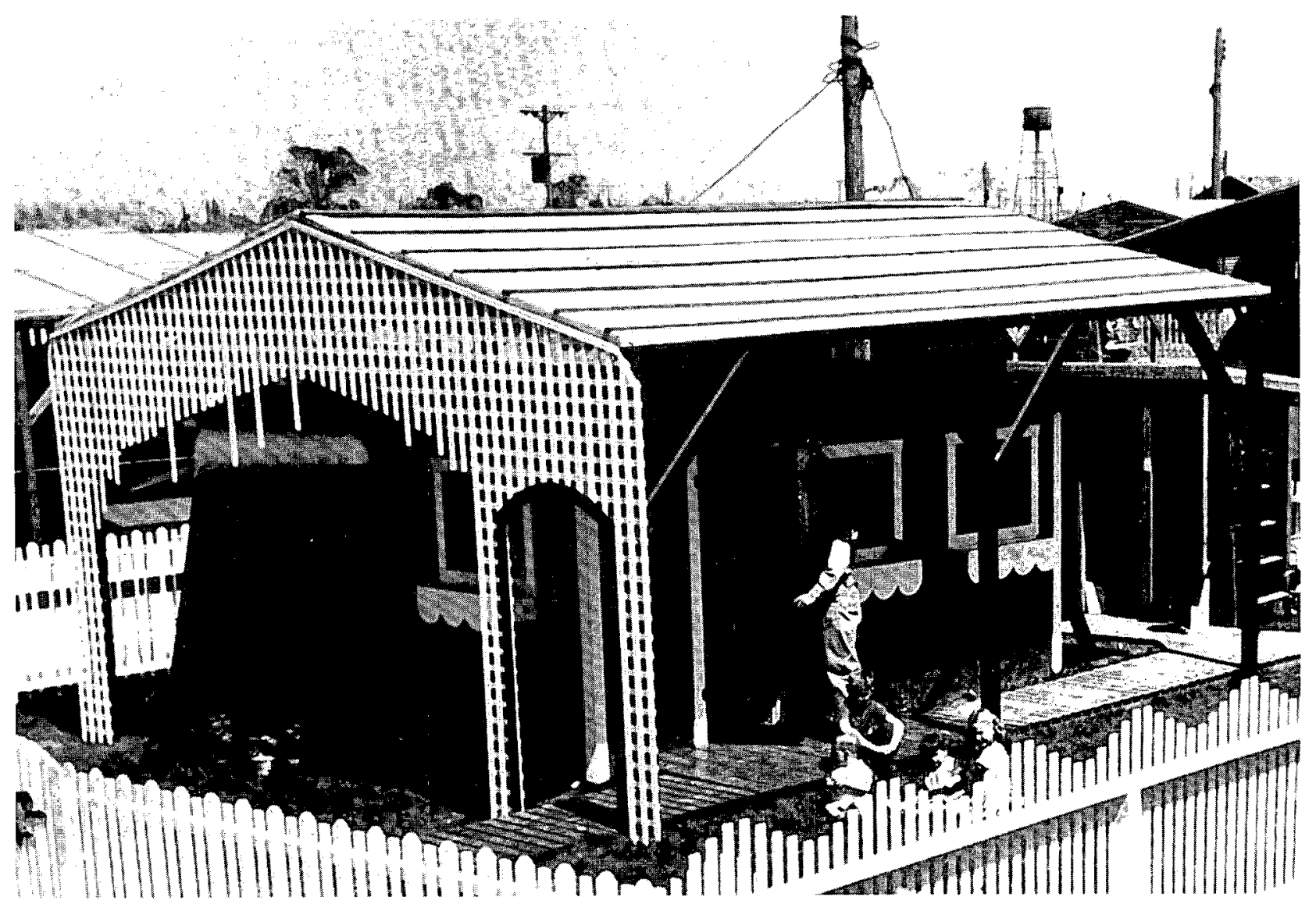

Trailer home to construction worker families in the special enclave of North Richland, created in 1947 to accommodate the thousands needed to build two new reactors, the Plutonium Finishing Plant, 42 more underground tanks, a chemical semi-works, and to enlarge government Richland. Single men lived in barracks along the Columbia River; within one year, North Richland housed 25,000 people. 


\section{First and Second Korean War Expansions (1950 - 55)}

In September 1949, the American nation was shocked by the Soviet Union's detonation of its first atomic bomb. The Hanford Works, just having completed a huge expansion-the largest peacetime construction project in American history up to that point-was plunged into another major growth surge.

\section{Communist Threat}

This expansion, lasting from 1950-52, received added impetus from other national and international developments that worried defense and espionage experts. Within eight months of the Soviet blast, Mao Tse-tung's Communist forces succeeded in driving Nationalist forces under Chiang Kai-shek from mainland China. Quickly, Mao signed a mutual assistance pact with Soviet dictator Josef Stalin. On June 25, 1950, Communist North Korean forces crossed south of the 38th parallel and ignited the Korean conflict. The United States, quickly assuming a lead in international affairs, supplied 90 percent of the troops fighting North Korea. During the same period, some of the most well-known spy cases in American history surfaced, including those of Klaus Fuchs, Julius and Ethel Rosenberg, and David Greenglass. In January 1950, the Alger Hiss conviction shocked the nation, and one month later Wisconsin Senator Joseph McCarthy launched four years of accusations that communists infested the American government and media.

\section{Widespread Atomic/Nuclear Expansion}

These events initiated the greatest era of expansion in U.S. atomic/ nuclear history. Congress increased defense appropriations, both for the U.S. and for the North Atlantic Treaty Organization, as early as three weeks after the U.S.S.R.'s atomic explosion. Between late 1949 and 1952, the Nevada Test Site was established and began trials with atomic weapons, and the Pacific Proving Ground (Bikini and Enewetak - formerly spelled Eniwetok - Atolls) was expanded and refurbished. The same period saw the founding of the Reactor Testing Station (now Idaho National Engineering Laboratory), the Paducah Gaseous Diffusion Plant (Kentucky), the Savannah River Plant (South Carolina), the Rocky Flats Plant (Colorado), the Pantex Plant (Texas), the Fernald Feed Materials Production Plant (Ohio), and the Sandia Laboratory (as a separate entity from Los Alamos). In January 1950, Truman approved development of the hydrogen (fusion) bomb, known at that time as the "Super."

\section{Further Expansion}

At Hanford, the reduction oxidation (REDOX) processing plant, the only continuous solvent extraction plant in the world, was completed and began operations in January 1952. REDOX used methyl isobutyl ketone (known as hexone) as the organic extractant, and aluminum nitrate as the "salting agent." It also used tall "packed columns" to achieve contact between the 
organic and aqueous phases of the process, thereby creating the need for the high, silo-like structure known as the "doghouse" or the "penthouse" at the end of the building.

Other facilities built during this expansion included C Reactor, which went critical in November 1952, a large Experimental Animal Farm and Aquatic Biology Laboratory in 100-F Area, and 18 more single-shell storage tanks for high-level waste. The chronic shortage of tank space led to the decision to build two evaporators, 242-B and 242-T. Beginning in 1951, they functioned to boil off low-level wastes for cribbing and to concentrate and reduce the volume of high-level wastes. The General Electric Company, prime contractor for the Hanford Works, also reorganized the site as the Hanford Atomic Products Operation (HAPO), and expanded its environmental monitoring program within the Health Instruments Division.

\section{A Salvaging Operation}

In 1952, U Plant, built during World War II but not needed as a processing canyon, was retrofitted as the Metal Recovery Plant. Its mission was to use a new tri-butyl phosphate/saturated kerosene (TBP-NPH) extraction technique pioneered by Hanford chemists to recover uranium from the waste stored in Hanford's tank farms. Because of this unique new chemical process, the $\mathrm{U}$ facility also became known as the "TBP Plant." At the time, the scarcity of high-grade uranium supplies made this mission crucial. Much of the U.S. supply of uranium was housed in Hanford's tanks! Unfortunately, this mission also generated unexpectedly large amounts of chemically complexed waste. Ferrocyanide was added to the waste stream to precipitate the cesium-137 component, thereby making wastes cascaded to successive tanks suitable for evaporation and concentration. The problems that have resulted from the ferrocyanide additions now constitute some of the most difficult ones in the Hanford Site cleanup program.

\section{A "New Look" and Single Strike}

Just as the first Korean War expansion was reaching completion, the election of President Dwight D. Eisenhower initiated yet another huge augmentation at HAPO. The new President, alarmed that the defense budget had tripled in the past three years, believed that a spending slowdown could be achieved by concentrating resources on atomic weapons rather than conventional forces. He called this policy the "New Look" in armaments. Unlike future arms planners who would develop varied targeting strategies, Eisenhower also believed that the U.S. needed a huge, single strike capacity. This policy was termed "massive retaliation." His beliefs, combined with the threat perceived by the explosion of the first Soviet hydrogen bomb in 1953, and with the need for plutonium for the embryonic American intercontinental ballistic missile development program, brought more rapid growth to Hanford.

\section{The Groundwork for Peak Production}

The second Korean War expansion at the site, sometimes known as the Eisenhower expansion, saw the construction of $\mathrm{KE}$ and KW Reactors, the Plutonium-Uranium (PUREX) Plant, and 21 more single-shell waste tanks. KE and KW were called the "jumbo" reactors, because their nameplate design power levels stood at 1,800 megawatts, 
whereas those of the earliest Hanford reactors stood at about one-fifth that level. The coming to power of the K Reactors in 1955 brought the total number of reactors operating in the Hanford Reach of the Columbia River to eight. The cumulative effects of their effluent, released into the Columbia after only a few hours in retention basins, began to attract the attention of the Atomic Energy Commission.

\section{Counting the Cost of Defense}

Scientists and physicians from the Division of Biology and Medicine conferred repeatedly with Hanford officials regarding potential threats to river life and safety. The PUREX Plant, which began test runs in late 1955, was a chemical engineering marvel of its day. Like the U Plant, it used tri-butyl phosphate diluted with saturated kerosene rather than the potentially explosive hexone as the extractant, and nitric acid rather than aluminum nitrate as the salting agent. The nitric acid then could be distilled and reused many times, thus reducing the radioactive waste volume. The PUREX Plant also used pulse columns, a more efficient system for achieving waste/solvent contact that also eliminated the need for the tall "doghouse" at the end of the building. However, despite other advantages such as built-in concentrators, it produced copious volumes of liquid wastes. Its initial average daily rate of 6.5 million gallons of low-level waste (cooling water and process condensate) disposed to the ground rose steeply during the late 1950s and increased groundwater mounds and radionuclide values in groundwater beneath 200 East. Site scientists, just catching their breath from the chemical and engineering problems of designing and running the many new facilities, began to turn more and more of their attention to the difficulties of managing the growing waste volumes. 
WHC-MR-0293

Revision 2

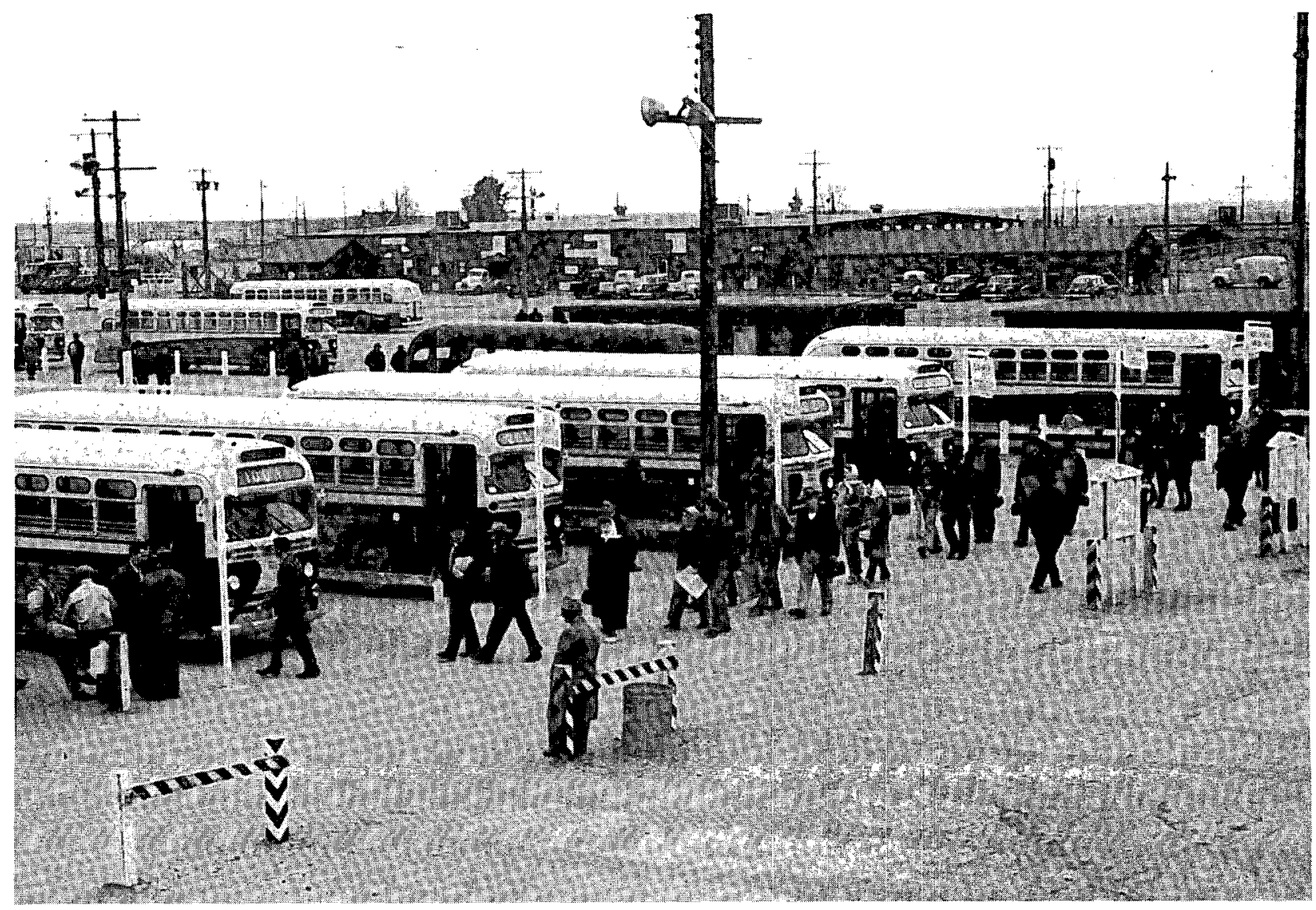

The 1100 Area Bus Lot was constructed in 1954. About 9,000 operating employees worked at the Hanford Site that year, with a total payroll of about $\$ 55$ million. By the end of the third postwar expansion in 1955, federal investments in plants and facilities at the eastern Washington atomic complex totalled just over $\$ 1$ billion. 
WHC-MR-0293

Revision 2

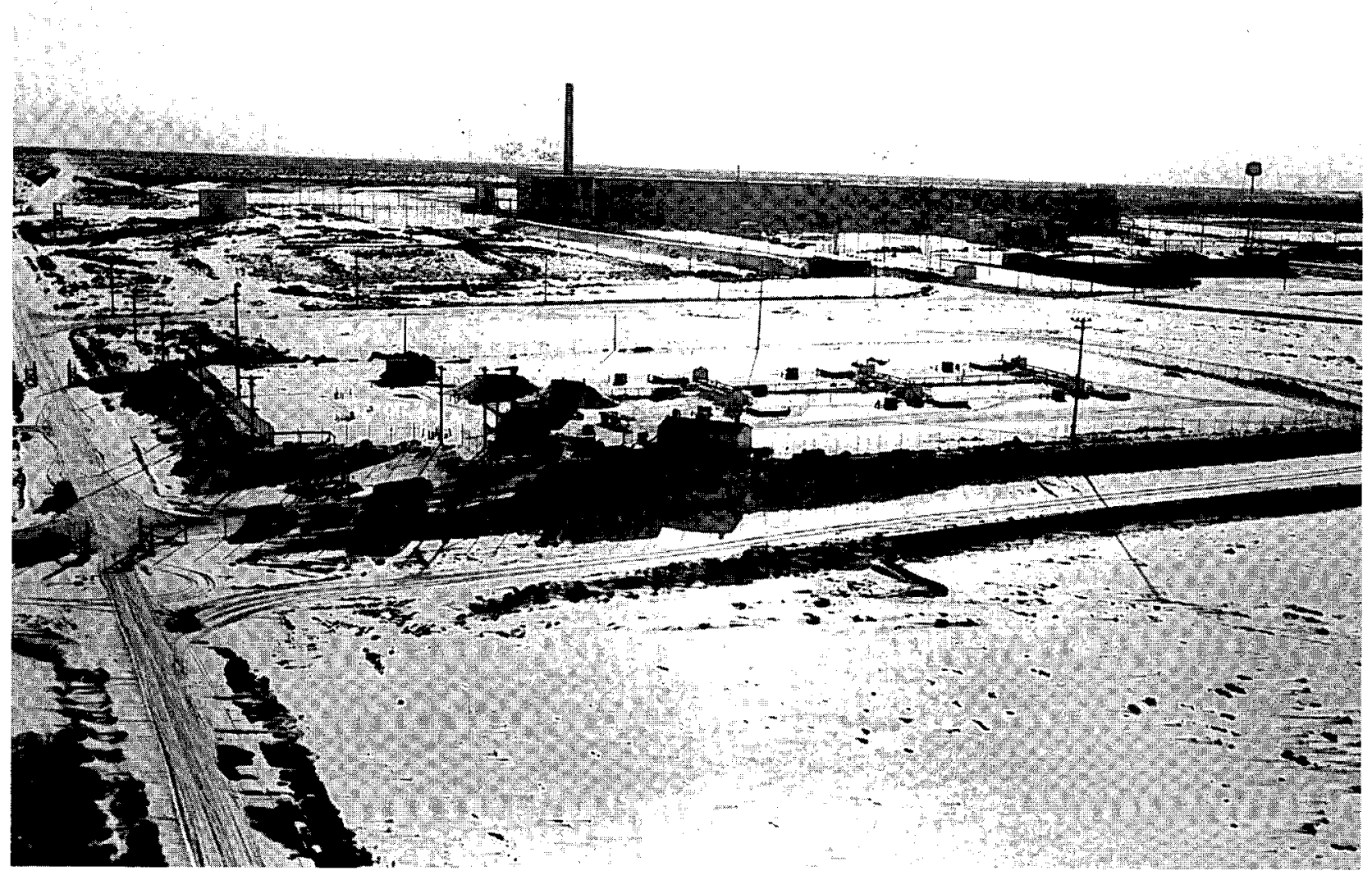

The PUREX (Plutonium-Uranium Extraction) Plant sits amid snow and uncleared construction debris in its first month of full-scale operation, January 1956. The most advanced chemical separations facility of its era, PUREX also proved to be a powerful waste generator. 
WHC-MR-0293

Revision 2

This page intentionally left blank. 


\section{Peak Years of Production at the Hanford Site (1956 - 63)}

The years 1956-63 witnessed the most intense defense production period at the Hanford Site. Cold War tensions, intensified by the coming to power of Nikita Khrushchev in the Soviet Union, drove the production of special nuclear materials. In 1955 , Khrushchev emerged as victorious in the two-year power struggle that followed the death of Soviet dictator Josef Stalin. A confrontational Cold Warrior, Khrushchev told Americans in a 1959 visit: "Your grandchildren will live under communism!" He launched Sputnik I, the world's first man-made vehicle to orbit the earth, on October 4, 1957. Within seven months, he had launched Sputniks II and III. These achievements combined with a dazzling string of other Soviet "firsts" in space, including the launch of over 120 orbiting satellites by 1966 , created a sense of national urgency in the United States. Clearly, this country would need nuclear power to energize instruments for its peaceful space exploration vehicles, and weapons material for its developing Polaris (Navy), Atlas and Minuteman (Air Force), and Jupiter (Army) missile systems.

\section{Iron Curtain Slams Shut}

In 1958, Khrushchev exacerbated world tensions by renewing demands that the North Atlantic Treaty Organization powers, former World War II allies, abandon their sectors of Berlin. When they refused, he angrily erected the Berlin Wall in 1961. The United States elected President John F. Kennedy in 1960. Kennedy campaigned on the pledge that he would close the "missile gap" with the U.S.S.R., and "get America moving again."
Policies that he initiated tripled the U.S. nuclear destructive capability by 1964 . He also traveled to Berlin to dramatically reaffirm the American resolve to stay in that city. "Ich bin ein Berliner" (I am a Berliner), he proclaimed. In the Cuban "missile crisis" of October 1962, he successfully challenged the Soviet attempt to emplace Inter Continental Ballistic Missiles in the western hemisphere. Hanford's weapons production, as it had done with President Dwight Eisenhower before him, gave Kennedy's words the backbone and the teeth to face down the determined U.S.S.R. Without that production, the course of history might have been quite different.

\section{Defense Production and Electricity Hand-in-Hand}

During the peak production years of 1956-63, very few new facilities were built at Hanford. The most outstanding new facility was $\mathrm{N}$ Reactor, a unique plant that combined plutonium production with the steam generation of commercial electric power. $\mathrm{N}$ Reactor began weapons production operations in December 1963 and started the Hanford Generating Project in 1966. Producing over 65 billion kilowatts in 24 years, $\mathrm{N}$ Reactor was the largest electric power producer in the nation in its early years.

\section{The Fruit of Research and Innovation}

Other new facilities constructed during the peak production years at that Hanford Site 
included the small, experimental Plutonium Recycle Test Reactor and Plutonium Fuels Pilot Plant, and the last four single-shell, high-level waste storage tanks. Major new capabilities also were added at Z Plant. There, the Recuplex operation, a method of reclaiming additional plutonium from various process scraps and wastes, had started in 1955. A criticality in April 1962 closed the Recuplex operation, but a larger and more sophisticated plutonium recycling plant, known as the Plutonium Reclamation Facility, opened at Z Plant in 1964. In the meantime, Hanford chemists were perfecting new ways of extracting various isotopes from separations plant processes and wastes. They pioneered a number of "isotope campaigns" in the late 1950 s and early 1960 s, producing megacuries of cerium, strontium, cesium, promethium and other rare earth elements for special military and NASA applications. During that period, Hanford was the world's only source for promethium, a rare earth element not found in nature. Hanford promethium was used by Donald W. Douglas in the development of the artificial heart.

In 1960, the "hot semi-works" (C Plant) at the Hanford Site began pilot runs to extract large amounts of strontium (Sr-90) from plant wastes. Soon after this process was perfected, $B$ Plant, the old wartime bismuth-phosphate separations plant, was retrofitted for a major strontium and cesium (Cs-137) extraction mission that ran from 1968-78.

\section{Counting the Cost of a Safe Western Hemisphere}

As the years of peak production went forward at the Hanford Site, volumes of wastes produced by the eight single-pass reactors, N Reactor, and the REDOX, PUREX, Z Plant and C Plant separations facilities increased sharply. A 1956 "feasibility study" (prototype for modern Environmental Impact Statements and Environmental Assessments required by the National Environmental Policy Act) resulted in the voluntary decision by Hanford managers not to construct additional single-pass reactors at the site. However, power and fuel exposure levels at the existing reactors were raised many times during the years of intense production to the point where each of the eight older reactors operated at power levels nearly ten times those of World War II. Such levels brought thermal increases and added chemical and radionuclide burdens to the Columbia River. The river was cooled by huge controlled spills of cold water from the bottom levels of Lake Roosevelt, behind Grand Coulee Dam, each summer from 1958-64.

By 1960 , reactor effluent (wastewater) discharges to the Columbia averaged 14,500 curies per day, after a four-hour decay period in the reactor retention basins. Hanford and Atomic Energy Commission leaders discussed rising levels of contamination in fish tissues in the river and in shellfish in coastal waters near the river's mouth. Chemists and operators at the site sought new practices that would reduce radionuclide formation in reactor effluent, or that would bind or transmute the isotopes in different disposal practices. Much time, effort and money were applied, but many research questions remained. During the same period, volumes of low-level wastes discharged to the ground also increased. Mounds in the water table beneath 200 East and 200 West grew larger, as did activity values in portions of the groundwater.

Concerned, site scientists began monitoring tritium and nitrates in groundwater in 1961. Additional test wells were drilled in many 
areas of the site. In the mid-1950s, suspected and sometimes confirmed leaks from single-shell, high-level waste storage tanks began. In 1958, the first comprehensive Hanford waste management plan was completed. This plan modeled the immobilization of high-level tank wastes. However, the requirements for radioisotopes for the burgeoning U.S. space program and for new medical applications were among the reasons that the plan was not implemented. Many Site and other officials believed that Hanford's wastes could be a source of valuable isotopes. Pioneering experiments in isotope extractions went forward at Hanford in the late 1950s and the 1960s.

On January 7, 1964, President Lyndon Johnson surprised the Hanford Site with his announcement of a decreased national need for special nuclear materials. "Hanford To Cut Back In 1965," proclaimed the local newspaper the following day. Thus, peak production at the eastern Washington desert complex began to slow down. 


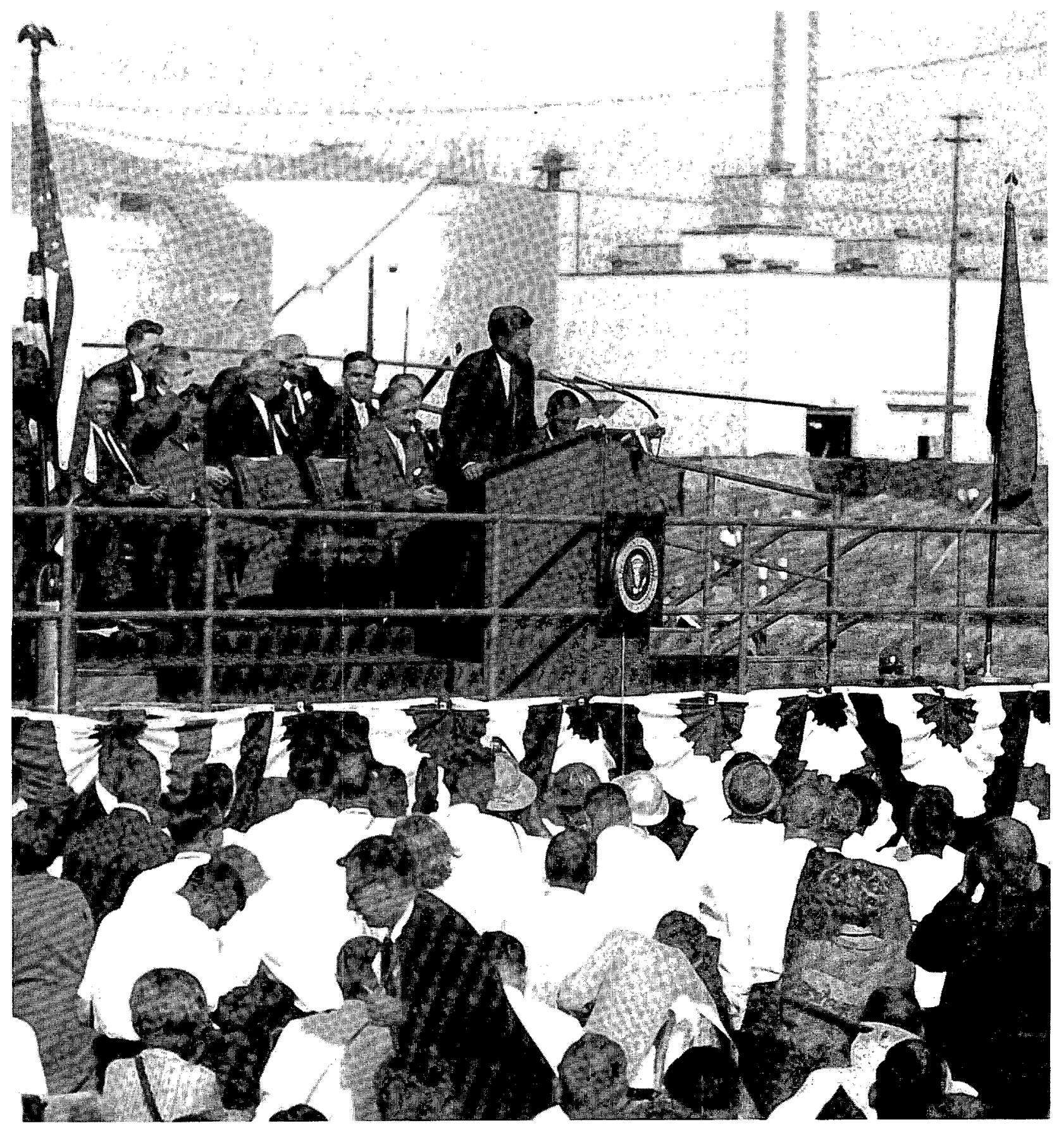

President John F. Kennedy addresses Richlanders and dignitaries assembled from around the state and nation at the dedication of N Reactor, September 1963. Actual start-up of this unique, dual-purpose (plutonium production and domestic electrical generation) reactor occurred three months later. 


\section{Hanford Site Wastes in the Columbia River}

The safety of the Columbia River from atomic wastes was among the earliest concerns expressed by the Manhattan Engineer District (MED) officials who built the Hanford Engineer Works (HEW). The economic value of the fishing industry, particularly the salmon catch, was affirmed by MED chief General Leslie Groves. Colonel Franklin T. Matthias, site commander, also noted the great love Northwest people had for the big river. The Columbia, the largest waterway flowing into the Pacific Ocean from the North American coast, is approximately 1,200 miles long. The Hanford Reach (not a term used in the 1940s and 1950s) stretches from about 300 to 350 miles upstream from the river's mouth and is a principal hatchery for salmon, steelhead trout, and, to a lesser extent, for white fish.

\section{Aquatic Monitoring and Protection Pioneer}

As a part of HEW reactor intake pipe design in 1943-44, Matthias sought the advice of fish experts and added mesh screens and other devices to protect small fish. "Inasmuch as we have made the definite commitment to...protecting the fish," he affirmed, "it is important that we live up to this, even though it costs money." General Groves made the early suggestion that the MED initiate fish irradiation studies, and, in a complicated contractual arrangement with the federal Office of Scientific and Technical Information, funded the creation of the Applied Fisheries Laboratory (later Radiation Biology Laboratory) at the University of Washington. University of Washington ichthyologist Dr. Lauren Donaldson was retained to direct the fish studies, and his colleague Richard Foster was brought to the HEW in June 1945 to direct onsite aquatic research. Foster stayed on at the site for nearly four decades, known by many throughout the years as "Mr. River." He later described his fledgling wartime irradiation experiments: "The fact that you even initiated a program under the stresses of war is very, very unusual."

\section{The Challenge}

After World War II ended, Matthias sought ways to continue funding aquatic research at Hanford, believing that the "biological data... will be of basic and fundamental importance." His viewpoint prevailed, and the Health Instruments Division of the DuPont Corporation and General Electric, and later divisions within Battelle Pacific Northwest Laboratories have continued Columbia River research for nearly five decades. These organizations had to attempt to answer questions about the effects of effluent in the waterway that, according to Herbert Parker, Hanford's first chief health physicist, were "almost completely unpredictable...at the time that the Hanford reactors were first energized." Would radioactivity cause certain species to fail to reproduce, or to reproduce in wild abundance, thereby upsetting the river's natural balance? Would the water itself be unfit to drink, even after filtration? Or would the food chain connection prove to be the most important? Would the tissues of fish and waterfowl that lived in and around the Hanford Reach attain radiation levels that made them unfit for consumption? Would chemicals in reactor 
water influent treatments cause disease epidemics in fish, and would thermal increases from effluent in the Columbia threaten salmon embryos and other young fish?

\section{Research Nets Results}

During 1946, several basic trends in the responses of fish to reactor effluent became evident. Young fish, possibly due to higher metabolic rates, accumulated proportionately more radioactivity in their tissues than did adults. Accumulation of radioactivity occurred more slowly in cooler water, and activity levels differed among various fish tissues. Consistently, livers, kidneys and gills contained the highest levels, while muscle tissue (flesh) demonstrated lesser amounts. However, the flesh tended to accumulate longer-lived radionuclides such as phosphorus-32, zinc- 65 , chromium-51, and plutonium-239.

\section{The Concentration Factor}

Importantly, Hanford's early aquatic biologists noted that the most basic levels of the river's food chain -- aquatic plants, algae, insects, crustacea, and smaller fish -concentrated radioactivity in their tissues at levels substantially higher than that of the water itself. Larger game fish, after consuming the river's biota, also possessed radioactivity levels higher than that of the water. By 1947, this trend had intensified to the point where the tissues of some fish in the Hanford Reach demonstrated concentration levels up to 170,000 times that of water in the Columbia. "This concentration factor," noted a site biologist, "is higher by a factor of several hundred than factors previously reported." Concerned, the aquatic researchers began a number of important fish, waterfowl, and limnological studies. In 1948, another site biologist summarized that the "concentrating ability" of the smallest and most basic organisms in the food chain was "in essence, the foundation of the radio-biological problem in the river."

\section{Questions Answered}

By this time, the results of numerous samples had shown that reproductive rates and general population balances among aquatic organisms in the Hanford Reach remained normal. Also, the Columbia River's water at the intake points for the Pasco and Kennewick domestic water supplies demonstrated radioactivity levels below permissible limits, and the slow sand and anthrafilt filtration beds used by city treatment plants allowed even more time for radioactive decay to take place.

\section{The Challenge Met}

Quantities of reactor effluent released to the Columbia River, along with total curie content, rose throughout most of the next 15 years. The construction of more reactors operating at increasing power levels caused these rises. During the same period, Hanford scientists contributed much effort, time and money to reducing the amount of radionuclides entering the river.

They experimented with new influent treatments, such as aluminum sulfate, to retard radionuclide formation, and with effluent treatments and disposal alternatives that might chemically bind the active isotopes. They focused on ways to reduce the number of fuel slug ruptures in the reactors and to detect ruptures sooner when they did occur. Such ruptures could elevate river contamination levels on a temporary basis. 
Also, recognizing that reactor "purges" (film cleansing operations) could increase radionuclide amounts temporarily, they limited the number and operating temperatures of such purges. Additionally, they reduced thermal increments by cooling the Hanford Reach with cold water from Lake Roosevelt, behind Grand Coulee Dam, every summer from 1958 to 1964.

Over the years, policies were developed at Hanford that diverted the more concentrated, 300-Area wastes to holding tanks, thus adding protection to the Columbia. The 1963 construction of $\mathrm{N}$ Reactor, with a closed circulating water coolant system, prevented most reactor effluent from entering the river.

\section{Little Remains}

All of the eight single-pass reactors at the Hanford Site closed between 1964 and 1971.
Quickly, radionuclide levels in river water and organisms decreased, and by 1975 , only a small measurable burden existed, mainly in the sediments of blind sloughs and of areas behind dams. In 1988, Congress passed a bill authorizing study of the Hanford Reach of the Columbia River for possible designation as a Wild and Scenic River. That study commenced in October 1989, but its report, scheduled for completion in September 1991, had not been released yet when this document was produced.

Meanwhile, along the shoreline and waters of the stunning Hanford Reach, sage grouse, American white pelicans, bald eagles, golden eagles, blue herons, salmon, steelhead, sturgeon, and many other unique animals make their homes, unconcerned with the people around them. 




Overhead and front-face views of the river pump houses (intake structures) built along the Columbia River during WWII. Each reactor area had such a facility, capable of pumping enough water to supply a city of 400,000 people. The Columbia's cold, pure water was one reason that the Hanford Site was selected.

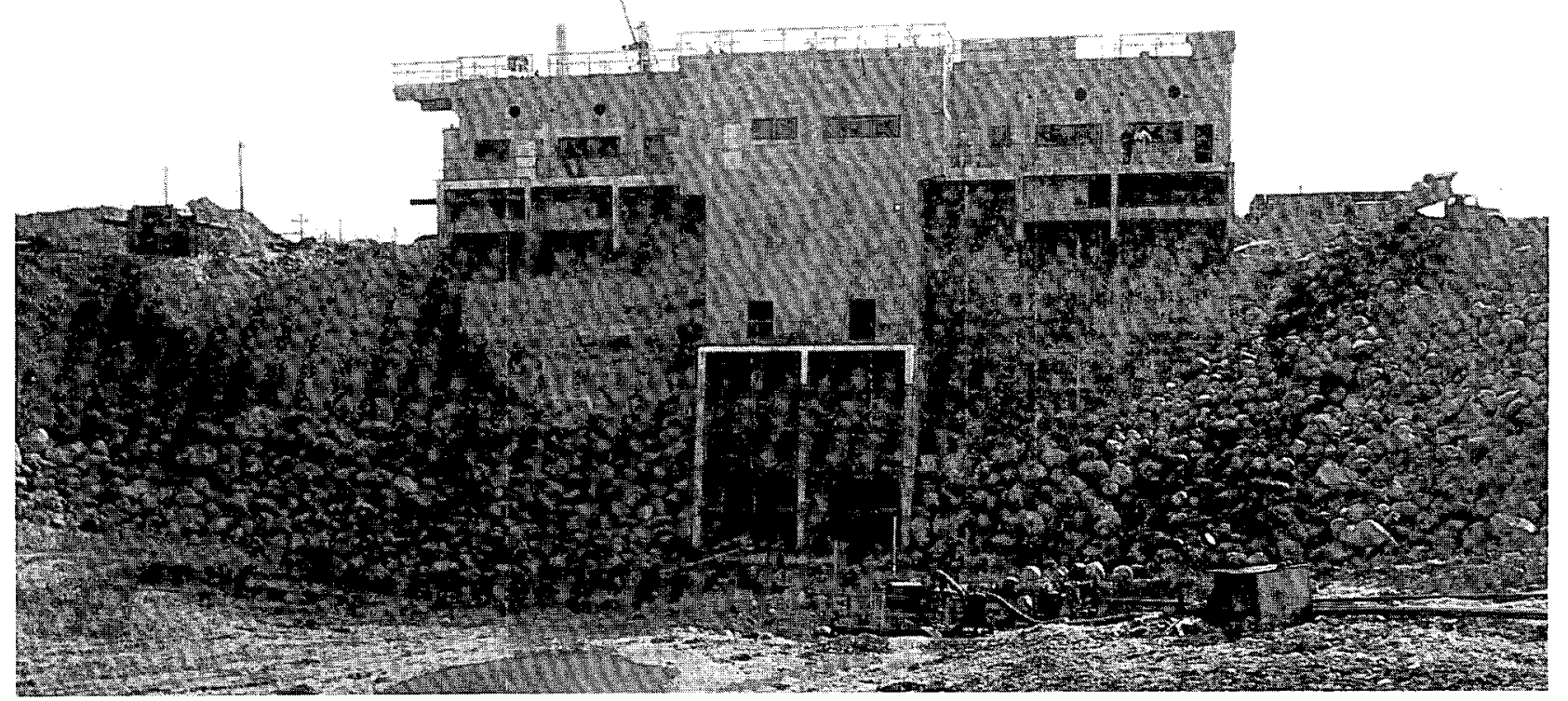




\section{Area Development}

The Hanford Site's 300 Area was conceived by Manhattan Project builders as a "process improvement" (research and development) and fuel fabrication area. Although it has grown over the years to encompass a fascinating array of projects, the basic 300 Area functions have not changed.

\section{Manhattan Project Essentials}

Over 30 structures were built in the 300 Area during WWII; five were of particular significance. Fuel fabrication operations took place primarily in the 313 Metal Fabrication and 314 Press Buildings. Uranium first arrived at HEW as extruded rods, which were machined down to fuel elements ("slugs") in the 313 Building. After the 314 Building's extrusion press arrived and became operational in January 1945, uranium was shipped to HEW as billets. Thereafter, the operations in 314 preceded those in 313 . The billets were cropped, extruded into rods, straightened and outgassed in 314 , then sent to 313 for jacketing or "canning." Graphite, uranium, aluminum cans and process tubes were tested in a QA program in the 305 Test Pile (reactor). During these early years, experiments to improve the new and untried bismuth phosphate separations process also were conducted in the 3706 Technical Building (old radiochemistry laboratory) and the 321 Separation Building. Soon the need to develop an even more efficient, continuous solvent extraction process led to the piloting of the reduction oxidation, Metal Recovery (U Plant), and plutonium-uranium extraction processes in these same two buildings.

\section{Production Expansions Bring Changes}

The large defense production expansions that increased the number of reactors, separations facilities and waste tanks at the Hanford Works in the early 1950s also led to growth in the 300 Area. In 1952-53, five large buildings, along with ancillary service structures, opened in the southern sector of that area.

The 325 Radiochemistry Building, complete with eight "hot" cells and a "reverse flow" ventilation system designed for work with radioactive materials, assumed many of the developmental missions of the old 3706 Building. The 325 Building, along with three other new structures, was connected to a Radioactive Liquid Waste Sewer that led to the new 340 Retention and Neutralization Complex for holding radioactive wastes for transport and disposal in the 200 Areas.

The 326 Physics and Metallurgy Building, known then as the Pile Technology Building, assumed the exponential pile physics studies that had been conducted in 189-D Building. In 326, approach-to-critical, lattice design experiments were conducted that led to safer, more efficient lattice configurations in the $\mathrm{KE}, \mathrm{KW}$, and N Reactors. The 327 Radiometallurgy Building also opened in 1953 , conducting both destructive and non-destructive examination of fuel rods and reactor process tubes. In the building's eight hot cells and two basins, failed fuel rods and corroded process tubes could be opened and probed to find clues to prevent future problems. 
The 328 Building, a large machine and fabrication shop that replaced four WWII shops, also was completed. That same year, the 329 Biophysics Laboratory opened to develop and use state-of-the-art radiation detection instruments for the pioneering Hanford Works environmental monitoring and bioassay programs. Later, the 329 Building would perform such exciting work as moon rock examination, fallout studies, oil shale, coal and Mt. St. Helens ash examination.

Soon after these buildings were completed, continuing defense production expansions brought major additions to many of them. The 325-A High-Level Radiochemistry annex, finished in 1960 and containing three much larger hot cells, plunged into multiple isotope separations campaigns for NASA programs in the 1960s, and into early waste vitrification work late in that decade. The 327 Building underwent four additions in the 25 years following its original construction. The most significant was the installation of the Special Environmental Radiometallurgy Facility cell, a large hot cell with an inert nitrogen atmosphere, electric manipulators, and the capacity to handle the heavy, eight-foot-long fuel rods used in the Fast Flux Test Facility (FFTF). The projected coming of $\mathrm{N}$ Reactor also led to construction of the 306 Metal Fabrication Development Laboratory (known as the Met Semi-Works) in 1956. This building doubled in size in 1960 , the same year that the $333 \mathrm{~N}$ Fuels Manufacturing Building (known as the Coextrusion Shop), constructed to house the unique fabrication processes needed for $\mathrm{N}$ Reactor fuel, was built.

\section{The Peaceful Atom}

The 1950s also were a time of expansive plans and dreams for the future of the "peaceful atom." President Eisenhower's "Atoms for Peace" program, announced in December 1953, and the passage of the new Atomic Energy Act of 1954, designed to allow for more private, commercial atomic applications, brought innovative, non-defense programs to the Hanford Atomic Products Operation (HAPO).

Because uranium fuel sources were scarce worldwide, it was important to experiment with alternate fuel mixtures and types. Anxious to participate in these new atomic frontiers, HAPO built the 308 Plutonium Fuels Pilot Plant (PFPP) and the 309 Plutonium Recycle Test Reactor (PRTR), both completed in 1960 . In the ensuing 16 years, the PFPP produced over 2,000 different fuel configurations, including uranium oxides, mixed oxides, plutonium and thorium blends, for trial in various non-defense reactors. The PRTR, a heavy water moderated, 100 megawatt experimental reactor, tested developmental fuels, process tubes, and the physics parameters of plutonium fuels. No defense materials were produced in the PRTR, but operating difficulties and national decisions to focus on the development of a Liquid Metal Fast Breeder Reactor (LMFBR) program forced its final closure in 1969.

From 1968-72, the 318 High Temperature Lattice Test Reactor operated to test powdered, pelletized and other experimental fuels at high temperatures. A dry nitrogen gas cooled reactor, it operated at $1,000^{\circ} \mathrm{C}$, but only at two kilowatts of nuclear power. The 324 Chemical Engineering Laboratory, completed in 1966 and planned to process and examine PRTR fuels, became a building 
without a mission as the PRTR's operations dwindled. In 1968, the four huge hot cells in the chemical sector of this building adopted the important new waste vitrification mission, and soon the metallurgical sector, known as the Shielded Materials Facility, became heavily involved in FFTF fuels examination. Over the years, major waste solidification missions and the processing of many Materials Open Test Assemblies for the FFTF have taken place in this building.

\section{LMFBR Research Brings New Additions}

The national decision to pursue LMFBR research in the late 1960s, and the subsequent efforts of Senator Henry Jackson, brought the prototype of such development, the FFTF, to the Hanford Site in 1970. Westinghouse formed the Hanford Engineering
Development Laboratory and constructed and/or modified many 300 Area structures to pursue FFTF research and development. The 335 and 336 Sodium Test Facilities, the 337 High Temperature Sodium Facility, and the 338 LMFBR Components Mock-Up and Maintenance Facility were among the most significant of these new buildings. In them, sodium loops tested various properties of sodium as a coolant, measured the behavior of mechanical components in a sodium environment, and fabricated, assembled and decontaminated equipment.

Today, like programs in other Hanford Site areas, 300 Area programs focus on the waste cleanup mission. Research and development directed at new remediation techniques, as well as at futuristic nuclear engineering applications, continues in many buildings. 


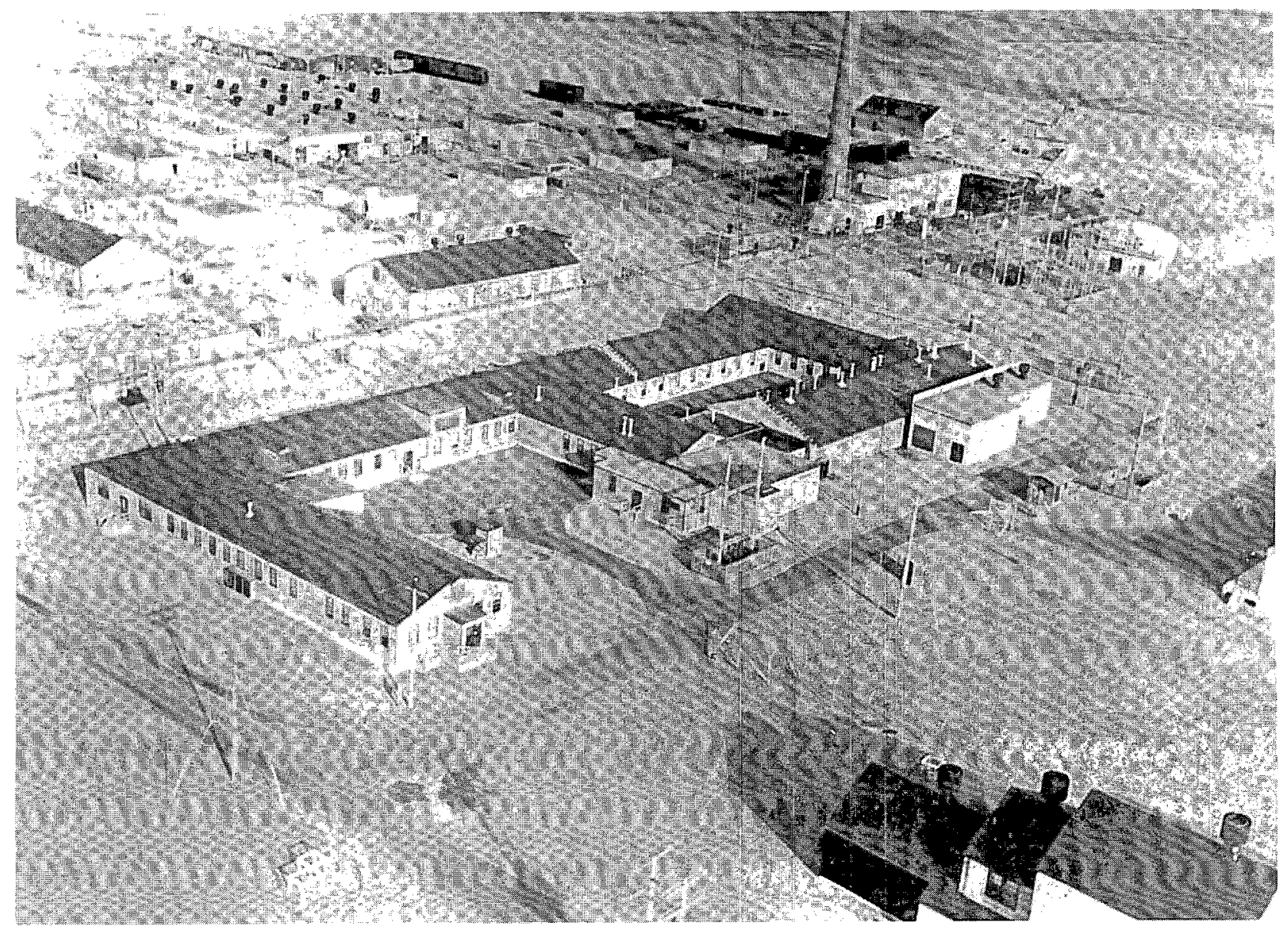

$H E W^{\prime}$ ' 300 Area, looking northeast, as it stood in 1945. The large, winged building in the center is the 3706 Technical Building (old radiochemistry laboratory). The 3745 Standards Building, housing the Site's instrument calibration facilities, casts a long shadow in the foreground. 
WHC-MR-0293

Revision 2

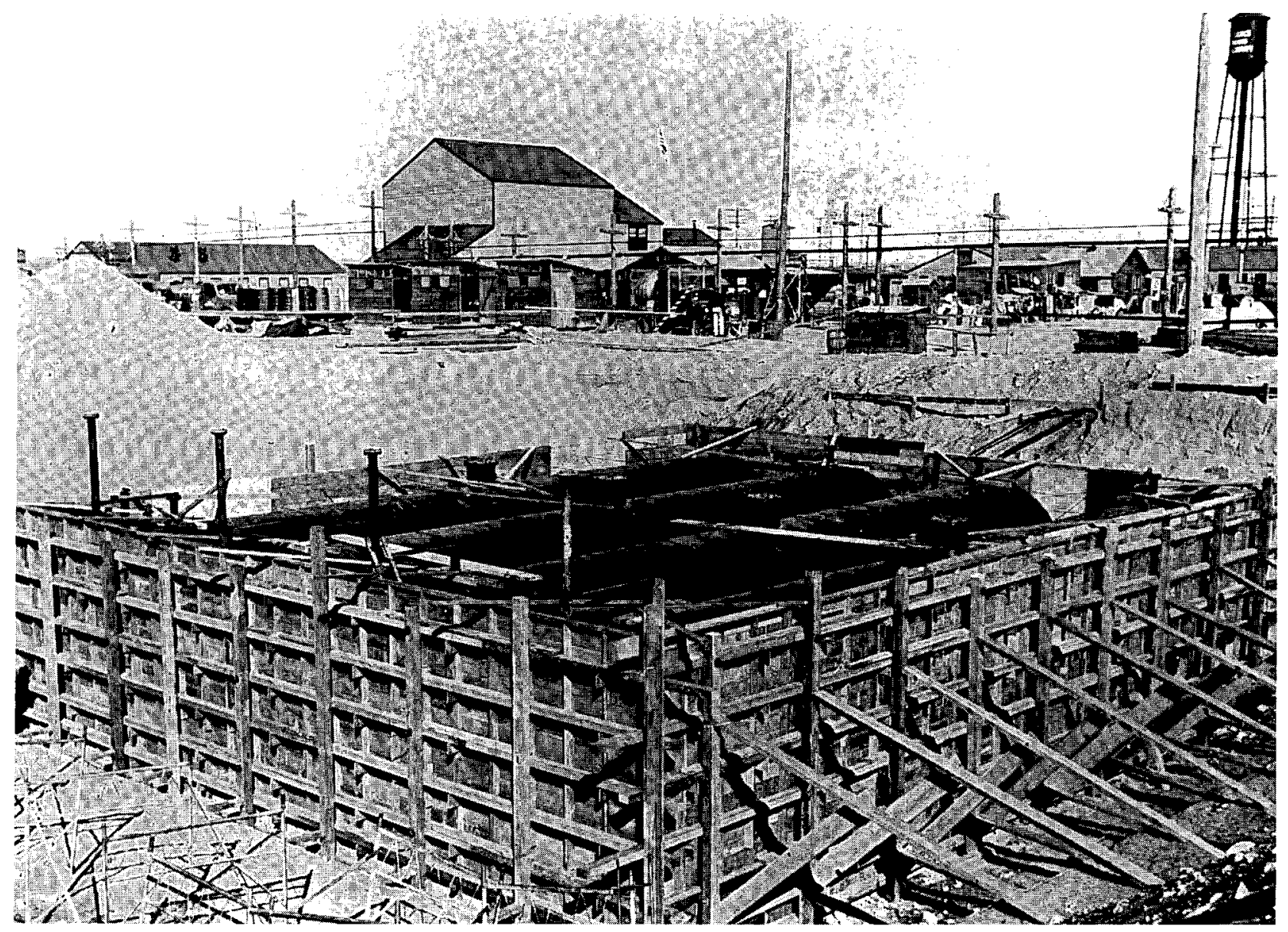

Underground waste storage tanks for the 321 Building being set in concrete in 1944. Ten feet in diameter and forty feet long, these four tanks received wastes from both "cold" (unirradiated) and "hot" (radioactive) chemical development trials over many years. They now present a difficult cleanup challenge. 
Revision 2

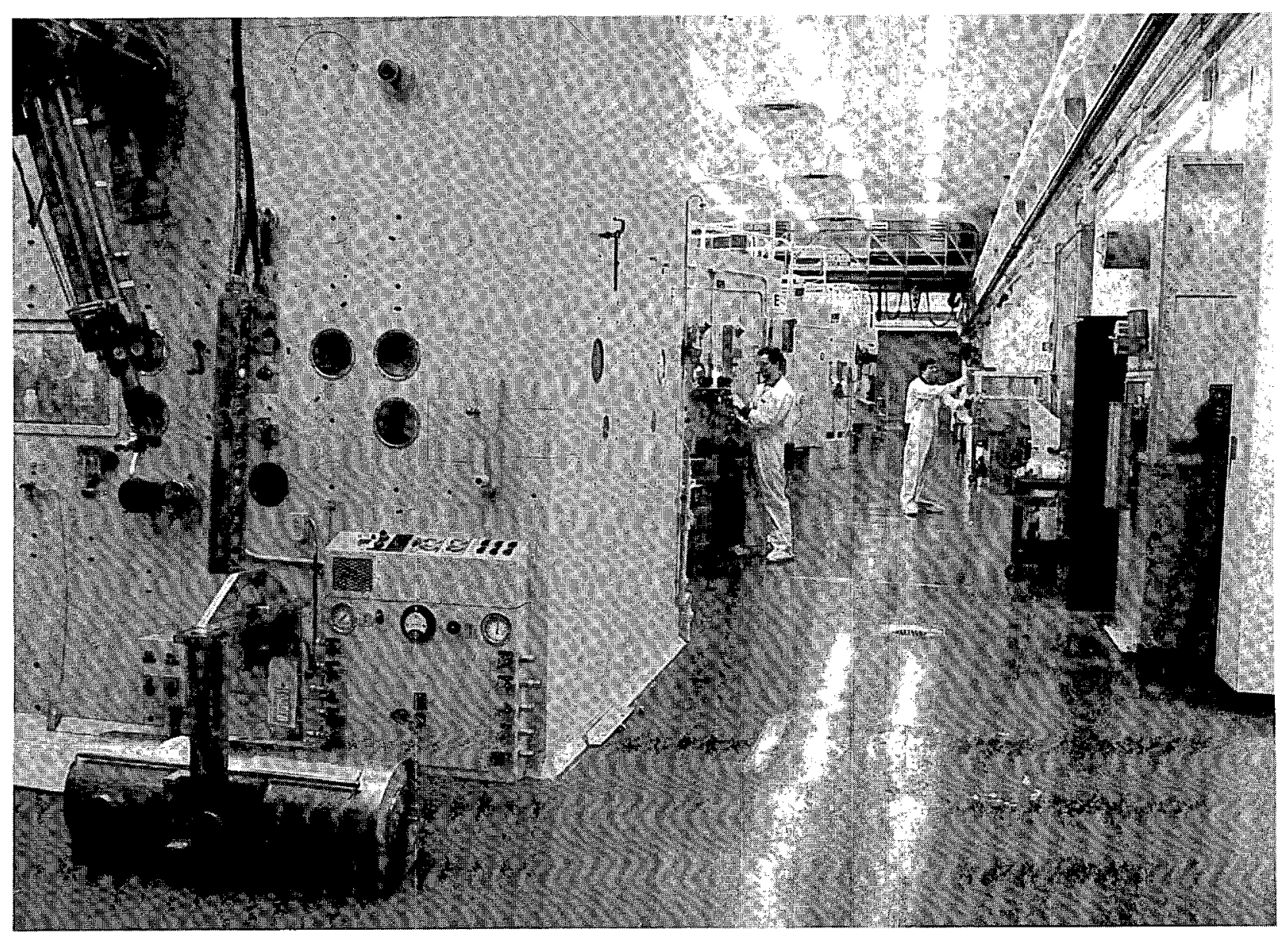

Eight small hot cells, carefully controlled environments to isolate highly radioactive processes, were built into the new 327 Radiometallurgy Building in 1952-53. Later, another small cell and the larger Special Environmental Radiometallurgical Facility (SERF) were added. Technicians check equipment in the "canyon" surrounding these cells in this later 1960s photo. 


\section{History of 200 Area Cribs and Tanks}

From the earliest operations at the Hanford Engineer Works (HEW), according to original chief health physicist Herbert Parker, liquid waste disposal to the soil column was "recognized as a temporary but necessary expedient... [conceived] to avoid absurd costs on tank storage, [or] evaporation equipment." The very first method of low-level liquid disposal was simply to pour wastes onto natural depressions in the soil. However, this practice was abandoned in the spring of 1945 , when the "swamp" areas receiving wastes demonstrated radiation readings higher than desirable. A series of "reverse wells" then were dug, and low-level liquid wastes were poured into these for the next two years. In mid-1947, the use of reverse wells was largely discontinued (although some such use continued for decades), because they often plugged with precipitates and sand and allowed the discharge of wastes too close to groundwater. That year the first Hanford cribs were constructed.

\section{Geological/Hydrological Investigations}

At the same time, preparing for a large production expansion and the beginning of a significant peacetime role for Hanford Works, the GE Company (prime contractor) scoured the nation for young college graduates in geology and hydrology. The first extensive exploration of subsurface conditions at the desert site began that autumn as many test and characterization wells were dug and laboratory studies were conducted in the migration of various radionuclides through sediments.
Among the most important early findings was the discovery that mounds (then called "distorted spheroids") had developed beneath the 200 East and 200 West Areas. The sheer volume of liquid wastes being disposed in these areas had caused the groundwater to rise to unnatural levels and had altered the underground drainage patterns so that liquid wastes traveled laterally, toward the Columbia River, faster than had been anticipated. At the same time, HEW scientists learned that plutonium, the prime radionuclide of concern, was quite well held (adsorbed) as soon as it entered local soils, but that other radionuclides such as cesium-137 and ruthenium-103/106 traveled much faster to and through groundwater. Chemicals such as sodium nitrate, present in process waste streams, also could speed the travel time of underground radionuclides.

Over the years, many additional studies were done to try to pinpoint travel time for specific wastes discharged from specific locations, as the underground mounds continued to grow. Peak levels occurred in the mid-1960s, following a ten-year period in which nearly 64 billion gallons of low-level liquid wastes were discharged to 200 Area soils. Today, these groundwater mounds still exist, standing at about 85 feet above pre-production levels beneath $200 \mathrm{West}$ and 25-30 feet above pre-production levels beneath 200 East. Working to comply with DOE Order 5400.5, the Hanford Site currently is developing treatment or containment plans for all of its active waste streams. 


\section{Tank Space Quickly Becomes Scarce}

Throughout Hanford Site history, high-level wastes have always been disposed to underground storage tanks, and tank space has always been limited. Sixty-four such single-shell tanks were built during World War II (B,C,T and U Tank Farms), and by late 1946, half of these tanks were 100 percent full and the other half were 40 percent full. During the first huge postwar expansion (1947-49), 42 more single-shell tanks (SSTs) were built (BX, BY and TX Tank Farms), and 18 additional ones (TY and $S$ Tank Farms) were constructed during the 1950-52 expansion.

\section{U Plant and REDOX Change Tank History}

In 1952, the opening of both U Plant (the Metal Recovery Plant) and the Reduction Oxidation (REDOX) Plant introduced new complexities in tank wastes. U Plant's mission to recover wasted uranium out of SSTs involved the sluice-mining of old wastes from underground storage tanks and a subsequent solvent extraction process that used tri-butyl phosphate and saturated kerosene. These processes created unexpectedly large volumes of chemically complicated wastes. In an attempt to conserve tank space, Site scientists "scavenged" the new U Plant wastes with ferrocyanide salts and nickel. After the cesium-137 precipitated to the bottom of tanks holding these wastes, much of the supernate was discharged to the ground. Today, both the presence of ferrocyanide in 24 (known) tanks, and the ground discharges resulting from the $U$ Plant mission constitute difficult cleanup challenges.
The initial operations of REDOX brought the first self-boiling wastes to Hanford's tanks. S Tank Farm contents began to boil in the summer of 1952, but the real problems arose the following winter, as cooling mechanisms not designed for self-boiling wastes froze and broke. A "swamp" of contaminated condensate and flooded cooling water, along with loud "bumps" from thermal releases in the tanks, caused problems throughout the winter of 1952-53. The new SX Tank Farm, then under construction, was fitted with air-lift circulators and mechanical augers, thermocouples, and interconnected condensers to accommodate self-boiling wastes. This fifteen-tank farm, along with the six tanks of A Farm, were built during the 1953-55 Eisenhower Expansion years at the Hanford Atomic Products Operation (HAPO). These and all subsequent single-shell tanks and double-shell tanks at the Site have been constructed to accommodate self-boiling wastes. During the large production expansions of the early 1950s at HAPO, extremely tight space limitations drove decisions to allow ground disposal of some wastes originally designated for storage in single-shell tanks. The last four single-shell tanks at Hanford (AX Tank Farm) were built in 1963-64. Since that time, 28 double-shell tanks have been constructed, and four new double-shell tanks currently are planned.

\section{Tank Waste Minimization an Ongoing Goal}

Over the years at the Hanford Site, tank waste minimization has been an important goal. Evaporators 242-B and 242-T began operations in 1951, and larger, more efficient evaporators 242-S and 242-A opened in 1974 and 1976 respectively. All are currently shut down, but 242-A is undergoing upgrades that will allow it to reopen within one year. 
Additionally, operations such as the In-Tank Solidification Program, the Stabilization and Isolation ("Salt Well") Program, and the 1968-1978 B Plant Strontium and Cesium Recovery Program have attempted to condense and/or separate high-level waste components so that more residual liquids can be disposed to the ground.

No tank leaks were reported at Hanford before the early 1950 s, although some pipes and fittings made from materials other than stainless steel did leak as early as 1945 . The first significant, confirmed tank leak occurred at $104-U$ in 1956 (55,000 gallons). The largest known leak from a Hanford single-shell tank occurred in 1973, when 115,000 gallons escaped from 106-T. Today, 66 single-shell tanks are listed as "assumed" leakers, but no double-shell tanks have leaked.

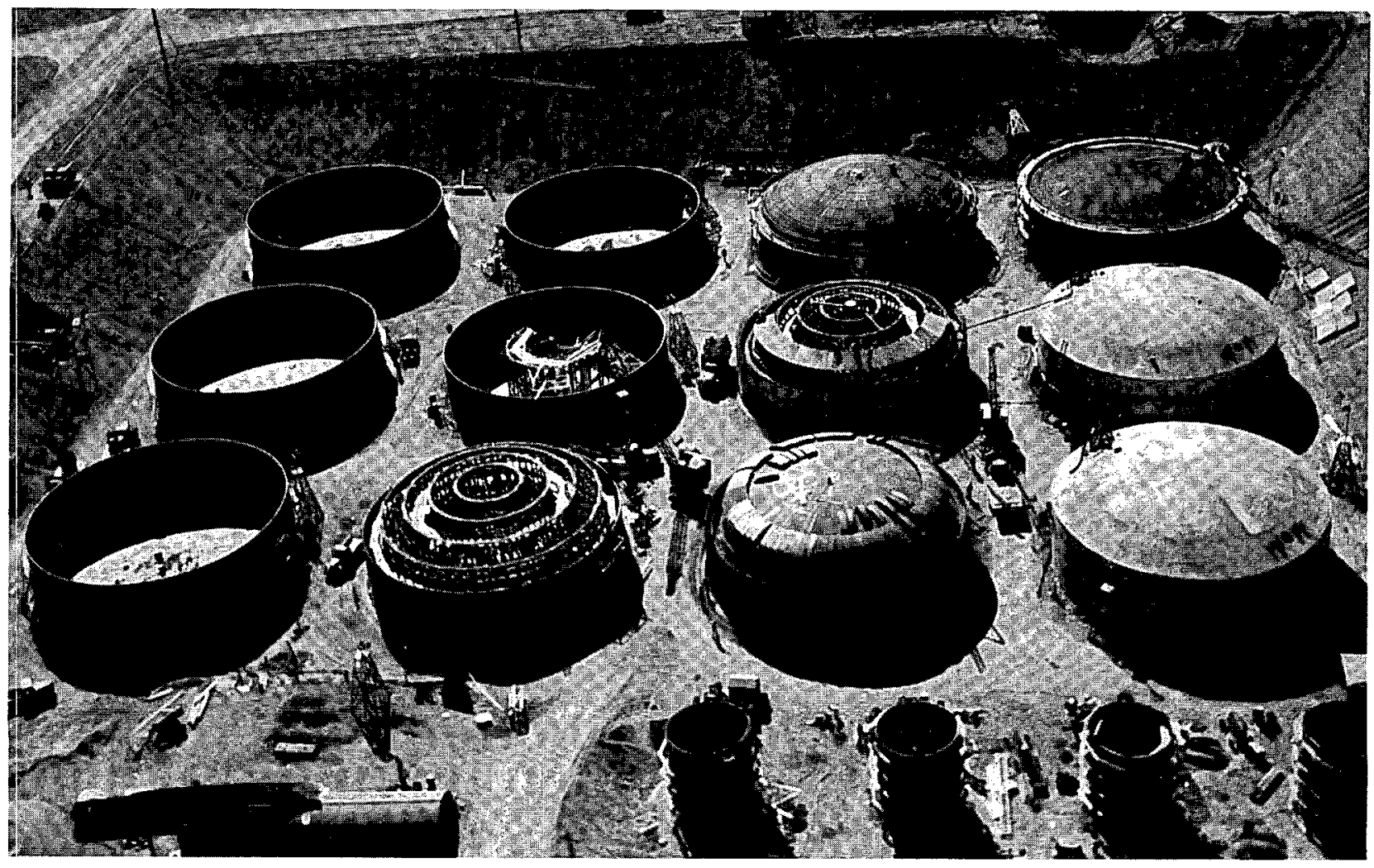

Tank farm of 16 underground single-shell tanks, for the storage of high-level atomic wastes, under construction during WWII. Four such clusters were built at wartime $H E W$, each containing twelve half-million-gallon tanks and the four 54,500-gallon tanks shown in the foreground. 


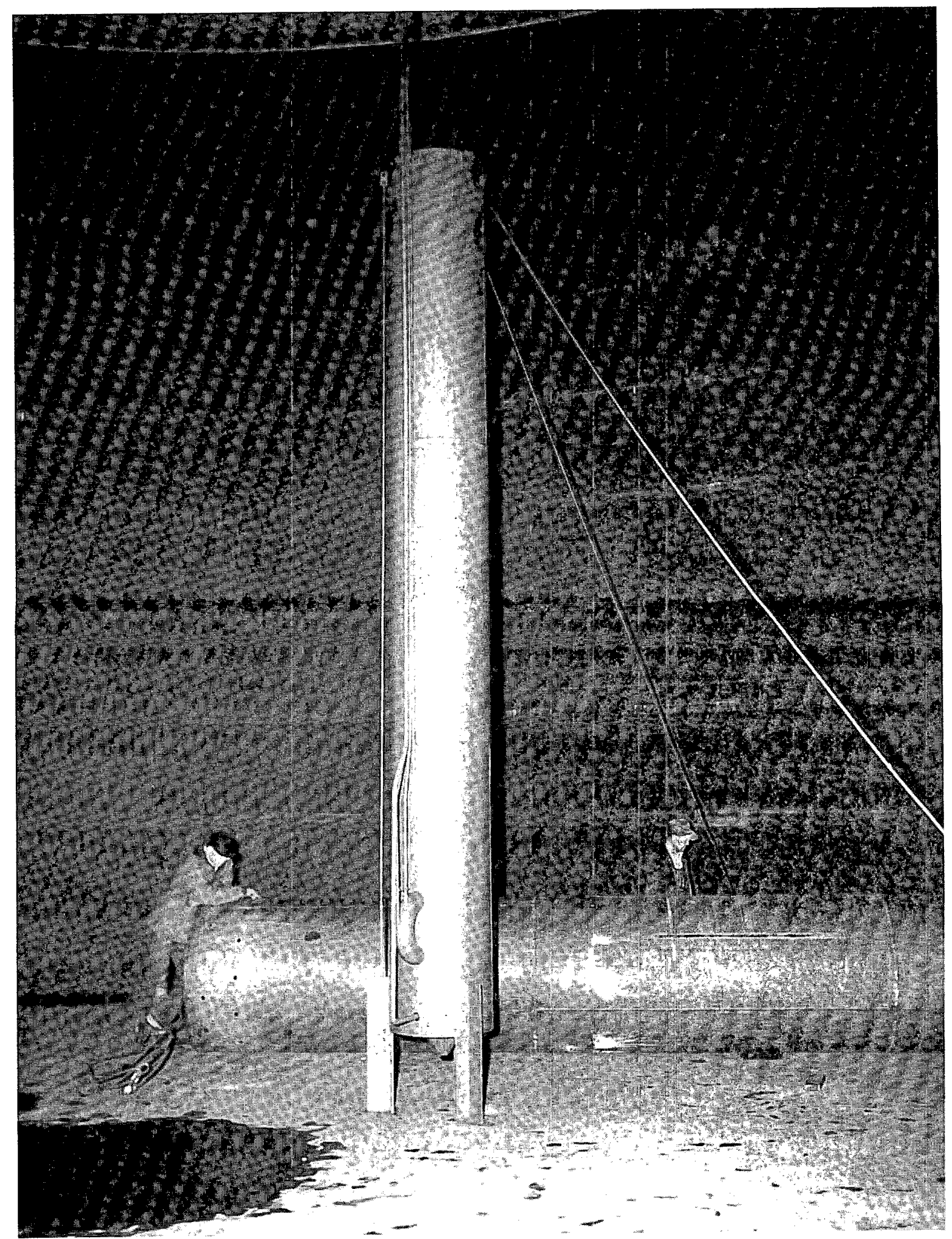

Air lift circulator being installed in a PUREX ("A" Farm) tank in 1955. This device would stir the wastes, thus avoiding the sudden escape of thermal bubbles generated by self-boiling wastes. 


\section{WHC-MR-0293}

Revision 2
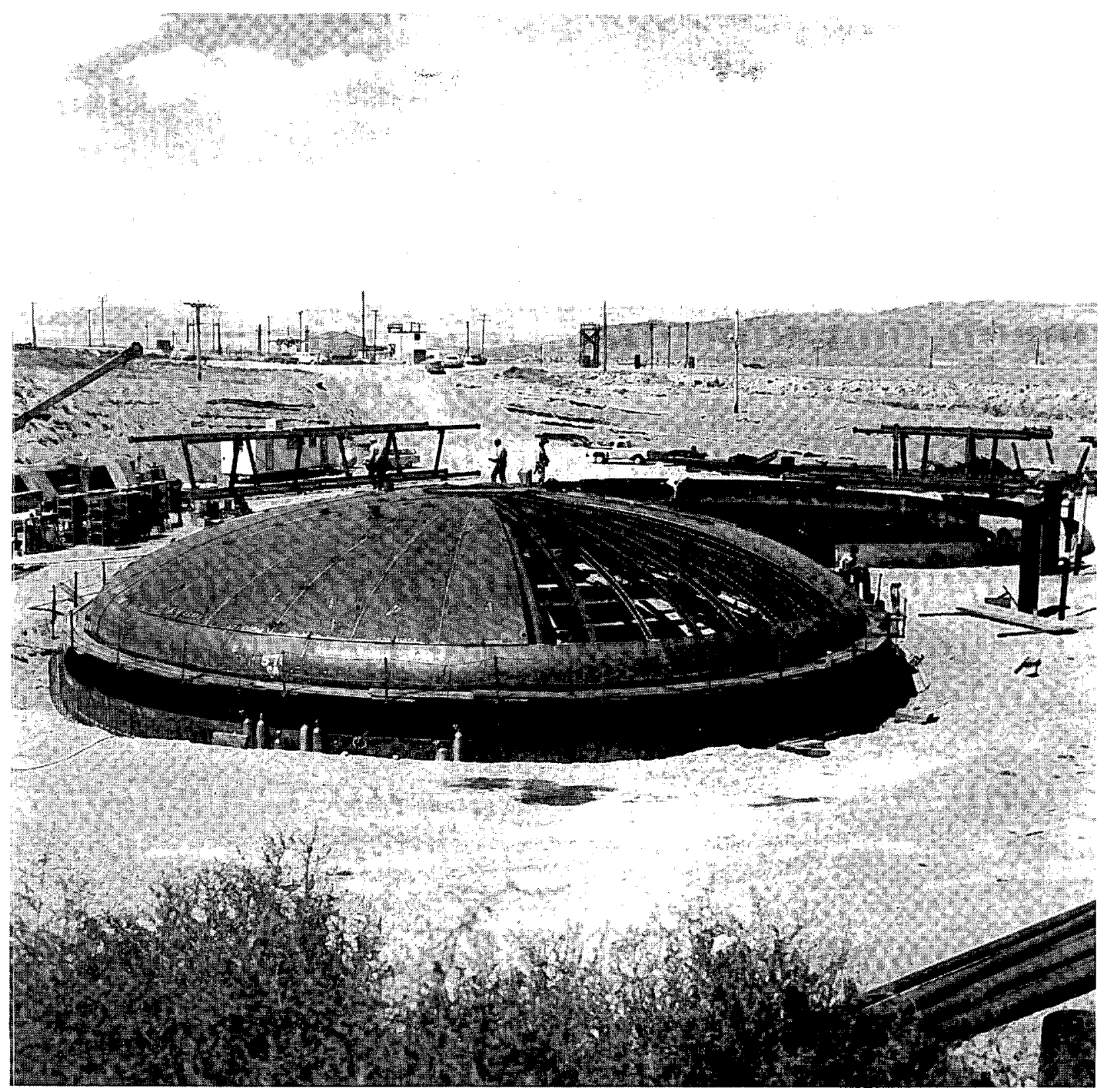

Double-shell tanks for the storage of high-level wastes, under construction in the early 1970s at Hanford Works. Twenty-eight such underground tanks were built at the Site between 1968 and 1986, and none have leaked. 
WHC-MR-0293

Revision 2

This page intentionally left blank. 


\section{Historic Structures at the Hanford Site}

Structures having historic significance in the United States can be considered for placement on the National Register of Historic Places if they are at least 50 years old and meet certain criteria. At the Hanford Site, many structures still standing from the original Manhattan Project construction era may meet the National Historic Preservation Act's requirement that they "are associated with events that have made a significant contribution to the broad patterns of our history." The advent of plutonium production at the Hanford Site must be seen as a significant event in the "broad pattern" of American and world history. And, between 1993 and 1995, many of the structures associated with the original plutonium production will become 50 years old. Although some potentially historic structures have been torn down at the Hanford Site, some exceptionally historic places still are available to inspire us.

\section{Reactor Association Formed}

\section{5-B Reactor is so well known that it} needs very little explanation. It was the world's first large-scale plutonium production reactor, becoming operational in September 1944. It was three months ahead of D-Reactor (December 1944), and five months ahead of 105-F (February 1945). In 1976, B Reactor was named as a National Mechanical Engineering Landmark by the American Society of Mechanical Engineers. In 1989, it was nominated by the U.S. Department of Energy (DOE) to the National Register of Historic Places (on an emergency basis, because it is less than 50 years old). That nomination is being reviewed according to National Historic Preservation Act procedures. In 1990, a B-Reactor Museum Association was formed in the Tri-Cities, aimed at preserving the reactor as a museum of the whole Hanford Site. Just this year, that community group received official recognition as a non-profit, tax-exempt educational organization.

B Reactor not only made possible atomic weapons production but also demonstrated the technology that led to commercial nuclear power generation.

\section{T Plant World's First}

221-T "Cell Building," known more commonly at Hanford as T Plant or $\mathrm{T}$ Canyon, is also extremely historic. When it processed its first batch of irradiated fuel rods from B Reactor on December 26, 1944, it was the world's first, large-scale plutonium separations facility. It was four months ahead of B Plant (April 1945). In conjunction with 224-T "Bulk Reduction Building," known to us as a concentration building, and with 231-Z "Concentration Building," known to us as the Plutonium Isolation Facility, $T$ Plant turned the irradiated fuel rods into a usable product-plutonium. The chemical process that took place in sequence in these three buildings was a batch operation that used repeated dissolution, precipitation and centrifugation to separate plutonium from uranium and associated fission products. It was called the bismuth-phosphate process. Essentially, it dissolved the aluminum-silicon jackets ("cans") that surrounded the fuel rods ("slugs"), then liquified the slugs themselves, and then achieved separation by varying the valent state of plutonium from +4 (the 
reduced state) to +6 (the oxidized, or hexavalent, state). The early radiochemists knew that plutonium would be carried in solution when it is in the +4 state but would stay behind when it is in the +6 state.

Through a series of decontamination cycles, the chemists were able to take plutonium through a series of precipitations, sometimes holding the plutonium in solution to concentrate it, and sometimes washing waste solutions away. The final Hanford Engineer Works (HEW) product throughout the World War II period was a wet plutonium nitrate paste. This product was concentrated and stored in small shipment cans (PR, or "product" cans) and placed in the $213 \mathrm{~J}$ and K Magazine Storage Vaults dug into the southeast end of Gable Mountain. (These vaults are of historic interest, but not "historic places" in the true sense of the National Historic Preservation Act.) Finally, the HEW product was shipped to Los Alamos, where it underwent the final processing steps that transformed it into plutonium metal.

\section{Other Historic Buildings}

Other historic buildings still stand at the Hanford Site.

The $212 \mathrm{~N}$ and P "Lag Storage" Buildings in the old 200 North Area were known as the "greening buildings" because they stored the irradiated fuel rods between the time they were pushed out of the reactors and the time they entered the processing canyons.

Beginning in 1946, HEW operators learned that it was easier and involved less contact time with the irradiated fuel elements if they stored them in water pools at the rear of the reactors. In recent years, the 212 Buildings have been used for the storage of polychlorinated biphenyls (PCBs) and some other wastes.
The 305 Test Pile (Reactor) in the 300 Area was the first operating reactor on the Hanford Site and was used as a quality assurance tool by Manhattan Project engineers. They needed to test the quality of the graphite, the uranium, and the aluminum fuel tubes and jackets that would be used in the large production reactors. Believing it would be too time consuming to test each batch of material with instrumentation and calculations, they simply tested samples from each batch in the 305 pile itself. They compared the performance of samples with the performance of materials of known quality and then graded each batch accordingly. The 305 Test Pile operated into the late 1960s at the Hanford Site and was pulled out of its building in the 1970s.

The 313 Metal Fabrication Building and 314 "Press" Building (known as the Metal Extrusion Building) in the 300 Area housed the fuel fabrication process at HEW. Arriving first as extruded rods, uranium was machined down to specific dimensions (four-inch and eight-inch "slugs") in the 313 Building. In this same facility, the slugs then were "canned" (jacketed or clad) in a "triple-dip" procedure that involved coating them with first bronze, then tin, and then an aluminum-silicon braze. They were then marked with a fluoroscope, end-machined, stamped with identification numbers, and the end caps were welded on. A final etching in hydrofluoric-nitric acid, followed by a methanol rinse, completed the fabrication procedures. Three final inspections then occurred; the first one (the frost test) took place in the 313 Building, and the final two, autoclave and radiograph testing, took place in the 314 Building. Beginning in late 1944 , uranium was shipped to HEW as billets. After extrusion press facilities in the 314 Building were installed and tested in early 1945, the fuel fabrication cycle at HEW changed slightly. From that time until 1948, 
the uranium billets first were taken to the 314 Building to be extruded into rods, straightened and outgassed. The rods then were taken to the 313 Building for machining into slugs, and for canning and frost testing. The 314 Building continued to house the autoclave and radiograph tests. In the early 1950 s, the canning method changed to a lead-dip process. A Hot Die Size (nickel-plating) canning process had just been developed when fuel fabrication operations stopped in the 313 and 314 Buildings in 1971.

The 321 Separation Building in the 300 Area, commonly known as the "cold semi-works," performed pilot-scale tests in process improvements for the HEW chemical separations plants using "cold" (unirradiated) or low-level radioactive materials. Later, in 1947-49, the reduction oxidation (REDOX) process was piloted in this building.

The 3706 Technical Building in the 300 Area was the earliest chemistry laboratory at $\mathrm{HEW}$, performing experiments in support of chemical process improvements until the "modern" radiochemistry laboratory (325 Building) was constructed in 1953.
Eight of the original 29 air monitoring stations (614 General Monitoring Stations) built by the Manhattan Project to sample air contaminants on and around the Hanford Site still exist. They are historic in that they represent the unique environmental monitoring programs that were pioneered at HEW.

The 622 Meteorology Tower was the core tool in the HEW air monitoring and protection program. Atmospheric studies and predictions were considered so important at HEW that oil fog tests were begun in the unfinished stack of T Plant in March 1944 and moved to $C$ Plant stack in July. That December, the 400-foot "Met" Tower was completed, and "dissolving forecasts," designed to predict wind dilution and dispersion factors over and around HEW, were issued every 12 hours. In May 1945, 24-hour dissolving forecasts, thought to have longer-term reliability, were begun. The meteorology program at the Hanford Site over the ensuing years has been one of the most extensive of any DOE site. 


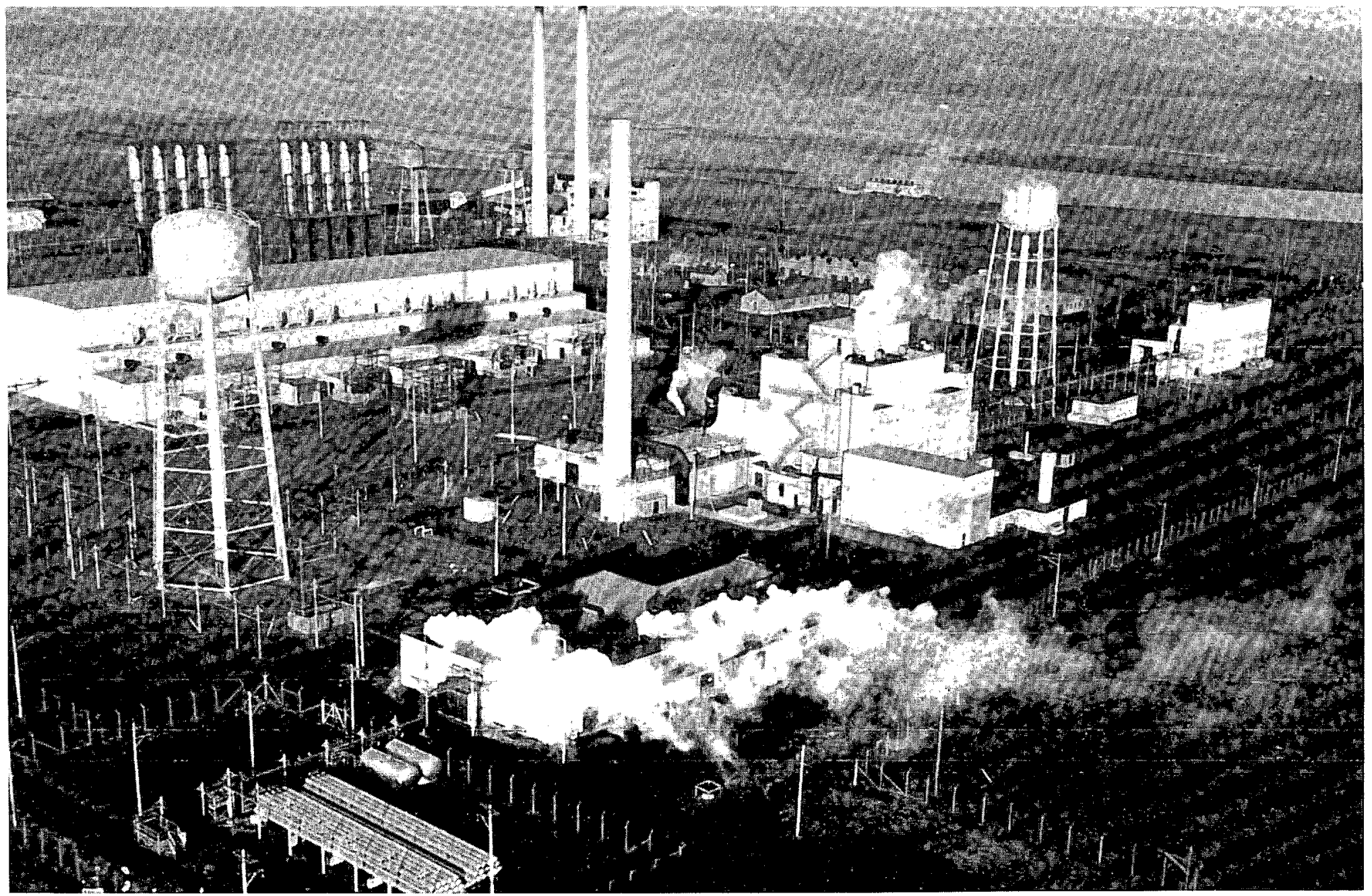

The 100-B Area, containing B Reactor, the most historic structure on the Hanford Site, as it stood in 1945. The reactor itself (the wedding cake-type structure near the photo center) was the world's first large-scale nuclear reactor, achieving initial criticality in September 1944. It has been nominated by the DOE to the National Register of Historic Places. The smaller structure to the far right in the photo is the 108-B Building, now torn down, which housed the first tritium separation processing conducted in the DOE (then AEC) complex. Tritium produced here between 1949 and 1952 was used in the first hydrogen weapons test explosions conducted at the Pacific Proving Grounds in late 1952. 
WHC-MR-0293

Revision 2

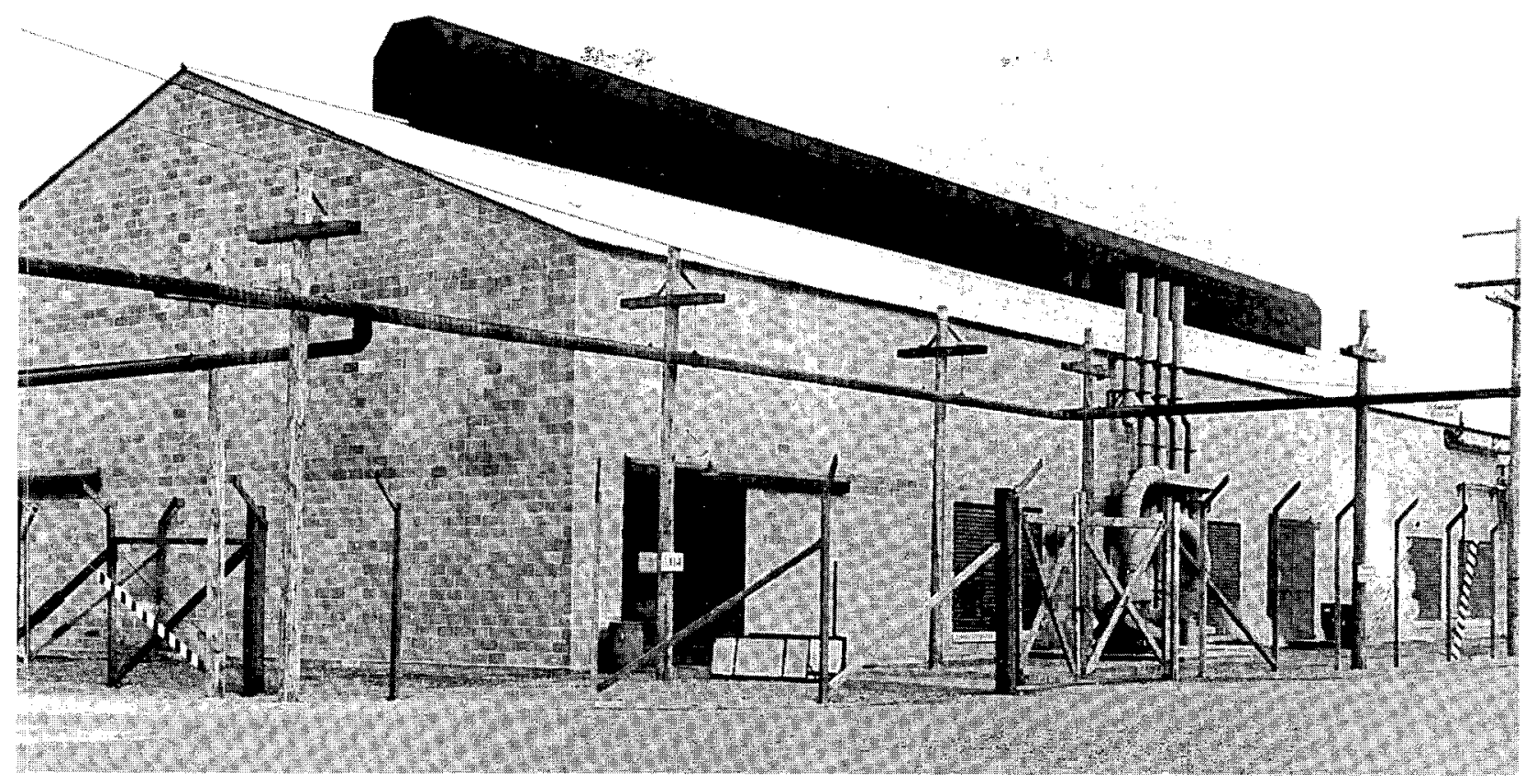

314 Press Building, in 1944. In this structure, uranium fuel rods for the Hanford Site's eight single-pass (original) reactors were extruded from billets, outgassed and straightened. Then they were sent to the nearby 313 Building to be jacketed (or "canned") with an aluminum-silicon coating, making them ready for insertion into the reactors.

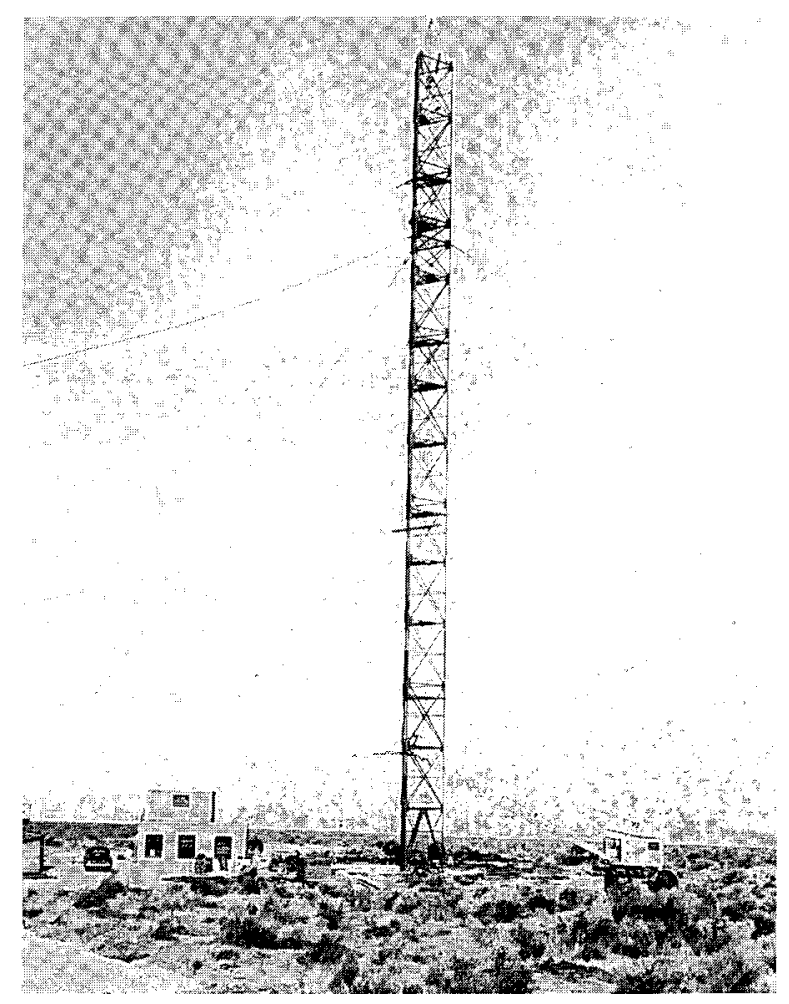

HEW's Meteorology Tower was complete enough for use on December 7, 1944. Using observation tests and forecasts issued at this structure, early Hanford operators scheduled chemical dissolving operations during weather conditions believed to be most favorable for atmospheric dispersion. The tower still functions as part of an official U.S. weather station. 